Prepared in cooperation with the Puerto Rico Department of Natural and Environmental Resources

\title{
Evaluation of Groundwater Quality and Selected Hydrologic Conditions in the South Coast Aquifer, Santa Isabel Area, Puerto Rico, 2008-09
}

Scientific Investigations Report 2012-5254 
Cover. View from north to south of the South Coastal Plain at the Santa Isabel area, Puerto Rico. Photograph by José M. Rodríguez, U.S. Geological Survey. 


\section{Evaluation of Groundwater Quality and Selected Hydrologic Conditions in the South Coast Aquifer, Santa Isabel Area, Puerto Rico, 2008-09}

By José M. Rodríguez

Prepared in cooperation with the

Puerto Rico Department of Natural and Environmental Resources

Scientific Investigations Report 2012-5254

U.S. Department of the Interior

U.S. Geological Survey 


\section{U.S. Department of the Interior \\ KEN SALAZAR, Secretary}

\section{U.S. Geological Survey \\ Marcia K. McNutt, Director}

U.S. Geological Survey, Reston, Virginia: 2013

For product and ordering information:

World Wide Web: http://www.usgs.gov/pubprod

Telephone: 1-888-ASK-USGS

For more information on the USGS--the Federal source for science about the Earth, its natural and living resources, natural hazards, and the environment:

World Wide Web: http://www.usgs.gov

Telephone: 1-888-ASK-USGS

Any use of trade, product, or firm names is for descriptive purposes only and does not imply endorsement by the U.S. Government.

Although this report is in the public domain, permission must be secured from the individual copyright owners to reproduce any copyrighted materials contained within this report.

Suggested citation:

Rodríguez, J.M., 2013, Evaluation of groundwater quality and selected hydrologic conditions in the South Coast aquifer, Santa Isabel area, Puerto Rico, 2008-09: U.S. Geological Survey Scientific Investigations Report 2012-5254, 36 p. 


\section{Acknowledgments}

The author wishes to thank the farm owners in the Santa Isabel area that permitted access to their properties during the data-collection phase of the study and provided valuable data related to water use and fertilizer application rates on their farms.

The author also wishes to thank USGS employees Senén Guzmán-Ríos, Kathleen McCarthy, and Michael Deacon for providing the internal reviews of this manuscript and Francisco Maldonado for the preparation of the illustrations.

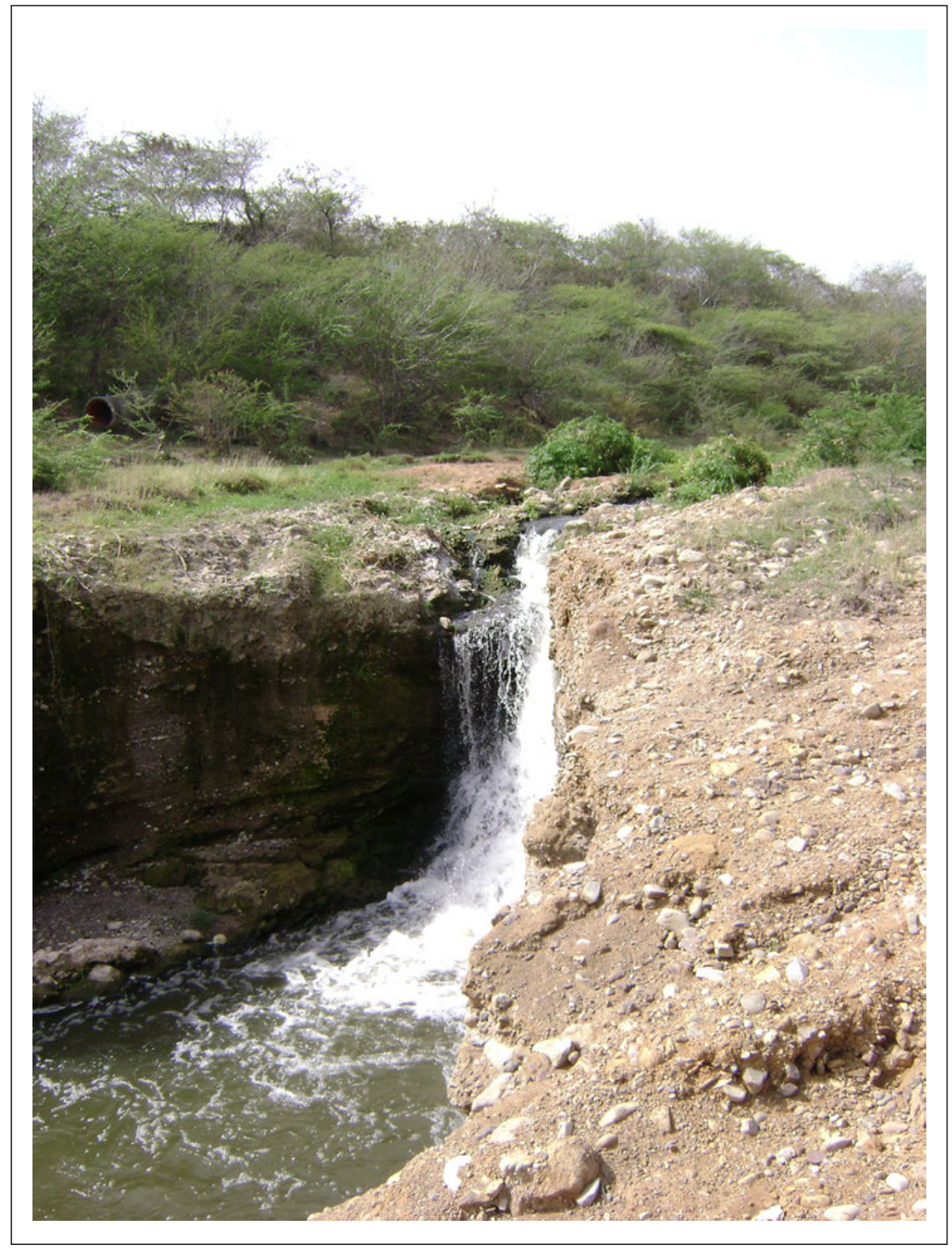

Río Coamo at Paso Seco area, Santa Isabel, Puerto Rico. Photograph by José M. Rodríguez, USGS. 


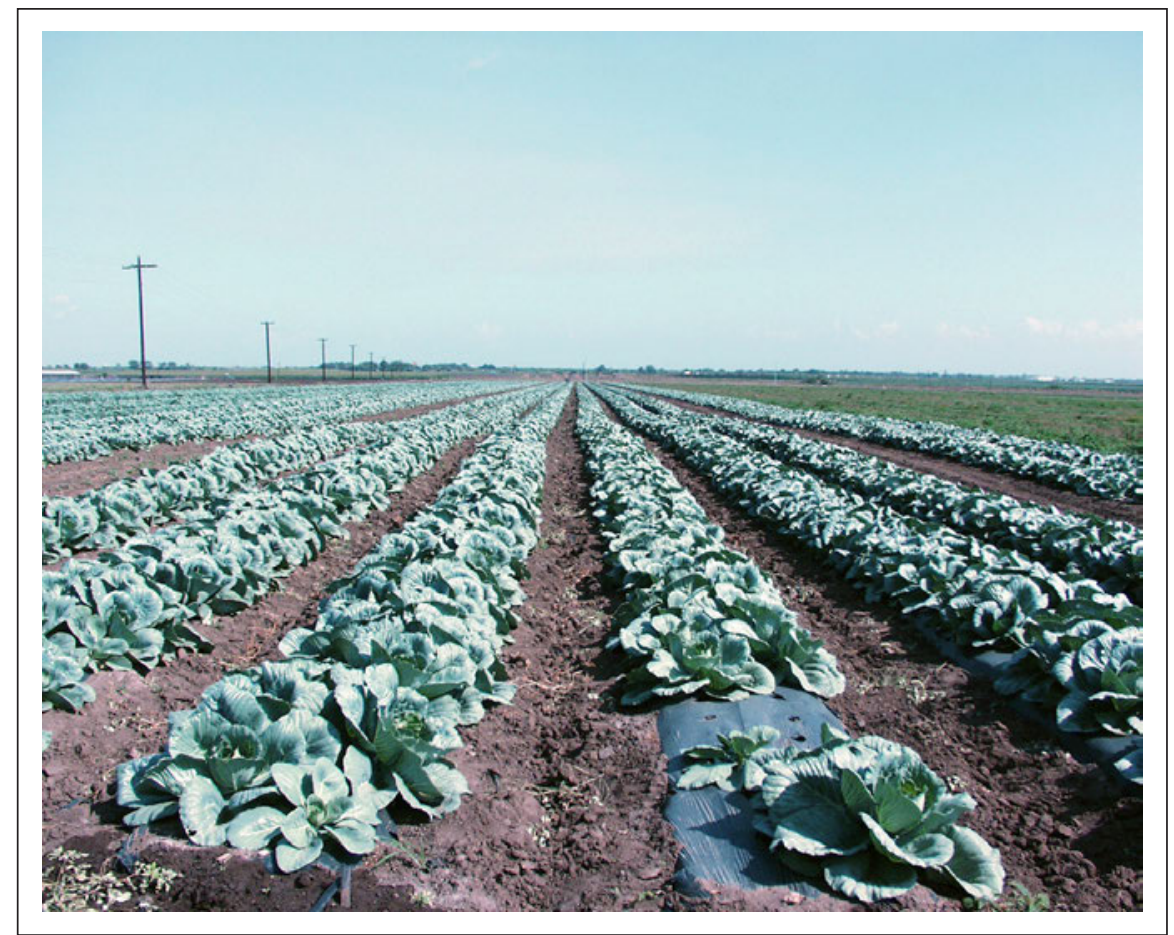

Row crops at the Santa Isabel area, Puerto Rico. Photograph by José M. Rodríguez, U.S. Geological Survey.

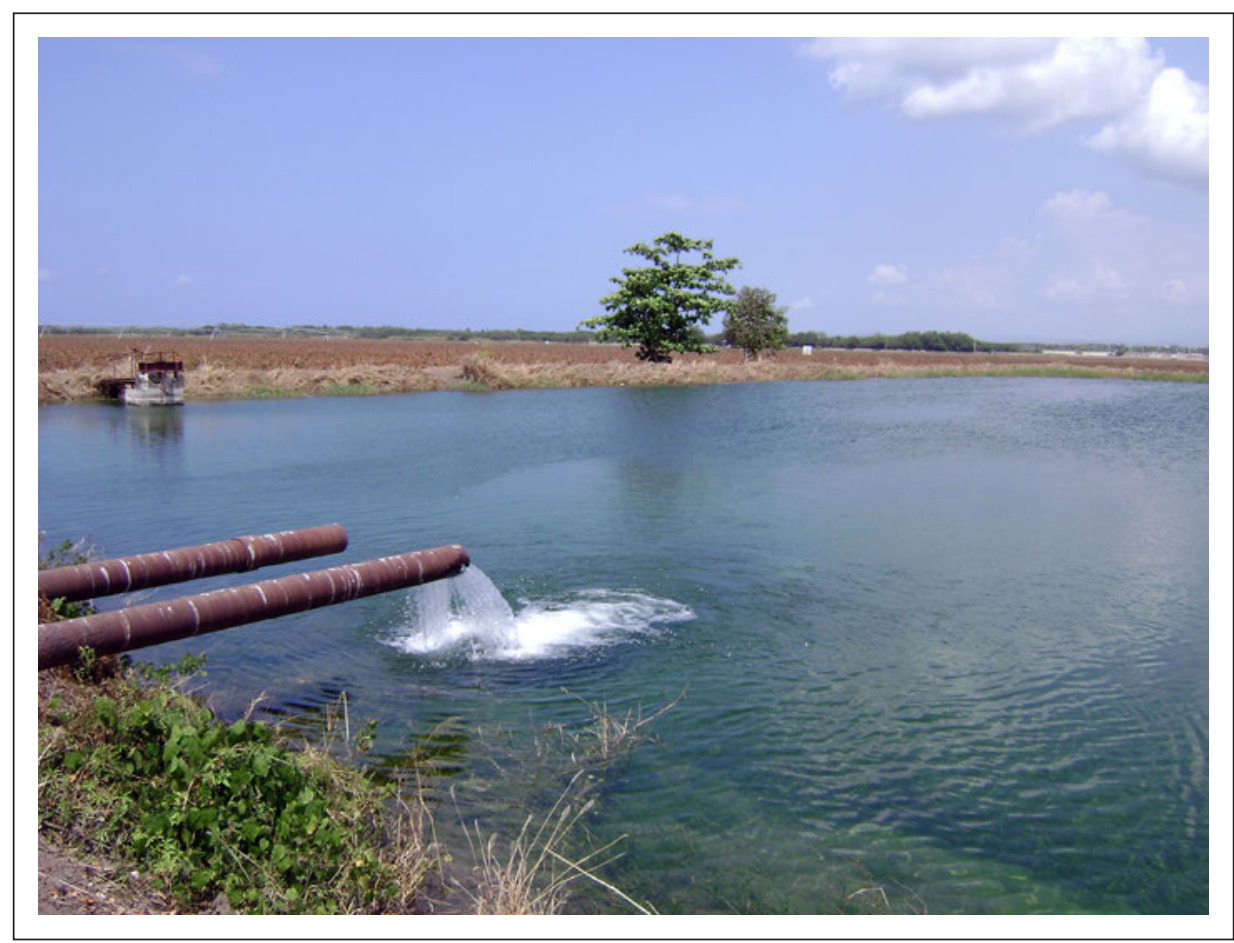

Irrigation pond at the Santa Isabel area, Puerto Rico. Photograph by José M. Rodríguez, U.S. Geological Survey. 


\section{Contents}

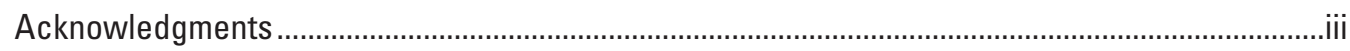

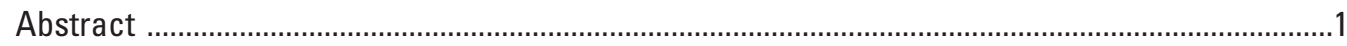

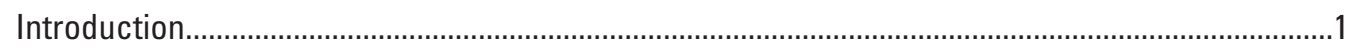

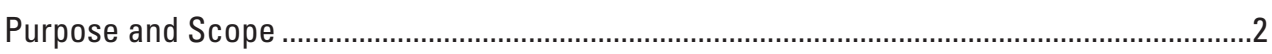

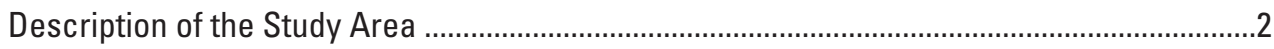

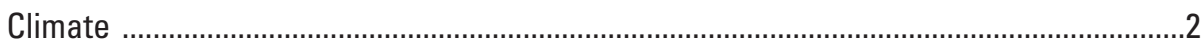

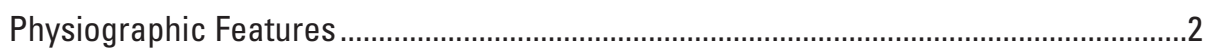

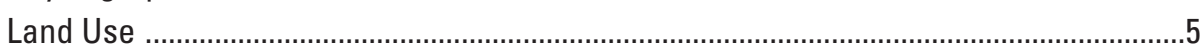

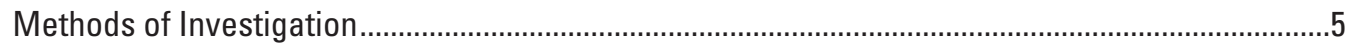

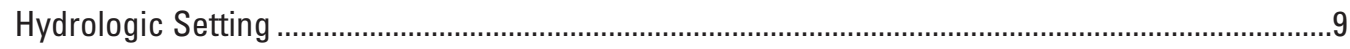

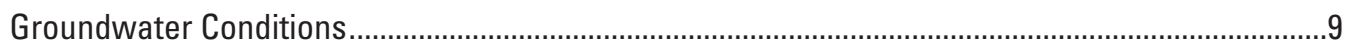

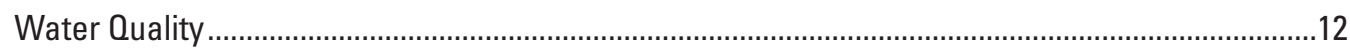

Specific Conductance and Dissolved Solids .......................................................................12

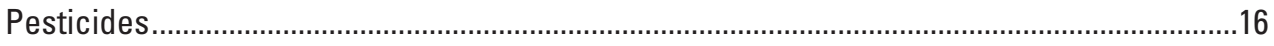

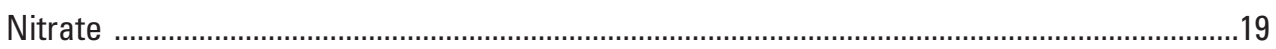

Sources of Nitrate ......................................................................................................... 19

Nitrogen and Oxygen Isotopic Characterization of Nitrate Sources ...............................23

Potential Nitrate Load to the Aquifer.................................................................................27

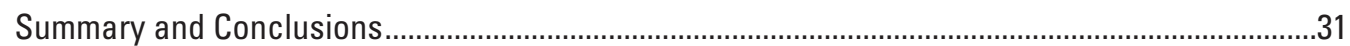

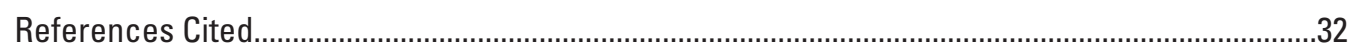

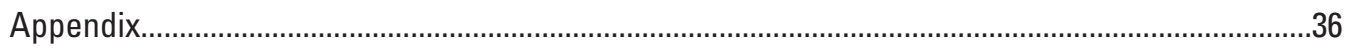




\section{Figures}

1. Map showing location of the study area in relation to the South Coast aquifer of Puerto Rico

2. Map showing location of data collection sites in the Santa Isabel area, Puerto Rico, 2008-09.

3. Graph showing distribution of monthly total and historical monthly mean total rainfall at the Santa Isabel 2ENE National Weather Service station, Santa Isabel, Puerto Rico

4. Map showing general land use in the Santa Isabel area, Puerto Rico, 2008-09

5. Map showing surficial geology in the Santa Isabel area, Puerto Rico

6. Map showing water-table configuration in the South Coast aquifer, Santa Isabel area, Puerto Rico, March 31-April 3, 2008

7. Graph showing water levels at site 44 , observation well Alomar 1 , Santa Isabel, Puerto Rico

8. Map showing specific conductance values in groundwater and surface water, Santa Isabel area, Puerto Rico, May 2008-April 2009.

9. Graph showing frequency of detection of pesticide compounds in groundwater samples collected from selected wells in the Santa Isabel area, Puerto Rico, May 2008

10. Map showing deethylatrazine-to-atrazine ratios in groundwater samples collected from selected wells in the Santa Isabel area, Puerto Rico, May 2008

11. Graph showing sum of detected concentrations of pesticide compounds in groundwater samples collected from selected wells in the Santa Isabel area, Puerto Rico, May 2008

12. Map showing nitrate concentrations in groundwater and surface water in the Santa Isabel area, Puerto Rico, during May 2008 to April 2009 and February to October, 1967

13. Graph showing relation of delta nitrogen-15 and delta oxygen-18 of nitrate in groundwater and surface water in the Santa Isabel area, Puerto Rico, May 2008-April 2009

14. Map showing delta nitrogen-15 and delta oxygen-18 of nitrate in groundwater and surface water in the Santa Isabel area, Puerto Rico, May 2008- April 2009.

15. Graph showing relation of the inverse of nitrate concentration and delta nitrogen-15 of nitrate in groundwater in the central section of the study area, Santa Isabel area, Puerto Rico, May 2008-April 2009.

16. Graph showing relation of the natural logarithm of nitrate concentration and delta nitrogen-15 of nitrate in groundwater in the central section of the study area, Santa Isabel area, Puerto Rico, May 2008- April 2009. 


\section{Tables}

1. Information for selected wells in the Santa Isabel area, Puerto Rico................................7

2. Nutrient concentrations and delta nitrogen-15 and delta oxygen-18 of nitrate in groundwater samples collected from selected wells in the Santa Isabel area, Puerto Rico, 2008-09.

3. Nutrient concentrations, delta nitrogen-15, and delta oxygen-18 of nitrate in surface-water samples collected from selected streams in the Santa Isabel area, Puerto Rico, 2008-09.

4. Pesticide compounds detected in groundwater samples collected from selected wells in the Santa Isabel area, Puerto Rico, 2008

5. Groundwater ubiquity score index for pesticide compounds detected in groundwater samples collected from selected wells in the Santa Isabel area, Puerto Rico, 2008

6. Potential nitrogen load estimates from fertilizers applied to crops and other sources in the study area, Santa Isabel, Puerto Rico, 2008.

7. Estimated nitrogen load from irrigation groundwater in the central and western sections of the study area, Santa Isabel, Puerto Rico, 2008

8. Potential nitrogen load estimates from fertilizers applied to crops and other sources in the central and western sections of the study area, Santa Isabel, Puerto Rico, 2008 


\section{Conversion Factors and Abbreviations}

SI to Inch/Pound

\begin{tabular}{|c|c|c|}
\hline Multiply & By & To obtain \\
\hline \multicolumn{3}{|c|}{ Length } \\
\hline millimeter $(\mathrm{mm})$ & 0.039 & inch (in.) \\
\hline meter $(\mathrm{m})$ & 3.281 & foot $(\mathrm{ft})$ \\
\hline kilometer (km) & 0.621 & mile (mi) \\
\hline \multicolumn{3}{|c|}{ Area } \\
\hline hectare (ha) & 2.471 & acre \\
\hline square kilometer $\left(\mathrm{km}^{2}\right)$ & 247.1 & acre \\
\hline hectare (ha) & 0.004 & square mile $\left(\mathrm{mi}^{2}\right)$ \\
\hline square kilometer $\left(\mathrm{km}^{2}\right)$ & 0.386 & square mile $\left(\mathrm{mi}^{2}\right)$ \\
\hline \multicolumn{3}{|c|}{ Flow rate } \\
\hline cubic meter per year $\left(\mathrm{m}^{3} / \mathrm{yr}\right)$ & 0.001 & acre-foot per year (acre-ft/yr) \\
\hline cubic meter per day $\left(\mathrm{m}^{3} / \mathrm{d}\right)$ & 35.31 & cubic foot per day $\left(\mathrm{ft}^{3} / \mathrm{d}\right)$ \\
\hline liter per second $(\mathrm{L} / \mathrm{s})$ & 15.85 & gallon per minute (gal/min) \\
\hline cubic meter per day $\left(\mathrm{m}^{3} / \mathrm{d}\right)$ & 264.2 & gallon per day (gal/d) \\
\hline millimeter per year (mm/yr) & 0.039 & inch per year (in/yr) \\
\hline \multicolumn{3}{|c|}{ Mass } \\
\hline $\operatorname{gram}(\mathrm{g})$ & 0.002 & pound avoirdupois (lb) \\
\hline kilogram (kg) & 2.205 & pound avoirdupois (lb) \\
\hline kilogram per year $(\mathrm{kg} / \mathrm{yr})$ & 2.205 & pound per year (lb/yr) \\
\hline \multicolumn{3}{|c|}{ Hydraulic conductivity } \\
\hline meter per day $(\mathrm{m} / \mathrm{d})$ & 3.281 & foot per day (ft/d) \\
\hline \multicolumn{3}{|c|}{ Flow rate } \\
\hline liter per second $(\mathrm{L} / \mathrm{s})$ & 15.85 & gallon per min (gal/min) \\
\hline \multicolumn{3}{|c|}{ Recharge rate } \\
\hline meter per year (m/yr) & 3.281 & foot per year (ft/yr) \\
\hline \multicolumn{3}{|c|}{ Production rate } \\
\hline gram per day $(\mathrm{g} / \mathrm{d})$ & 0.035 & ounce, avoirdupois, per day (oz/d) \\
\hline \multicolumn{3}{|c|}{ Application rate } \\
\hline kilograms per year (kg/yr) & 0.892 & pounds per acre per year (lb/yr) \\
\hline \multicolumn{3}{|c|}{ Application rate per area } \\
\hline $\begin{array}{l}\text { kilograms per hectare per year } \\
(\mathrm{kg} / \mathrm{ha}) / \mathrm{yr}\end{array}$ & 0.892 & pounds per acre per year (lb/acre)/yr \\
\hline
\end{tabular}


Temperature in degrees Celsius $\left({ }^{\circ} \mathrm{C}\right)$ may be converted to degrees Fahrenheit $\left({ }^{\circ} \mathrm{F}\right)$ as follows:

${ }^{\circ} \mathrm{F}=\left(1.8 x^{\circ} \mathrm{C}\right)+32$

Temperature in degrees Fahrenheit $\left({ }^{\circ} \mathrm{F}\right)$ may be converted to degrees Celsius $\left({ }^{\circ} \mathrm{C}\right)$ as follows:

${ }^{\circ} \mathrm{C}=\left({ }^{\circ} \mathrm{F}-32\right) / 1.8$

Vertical coordinate information is referenced to local mean sea level.

Horizontal coordinate information is referenced to the Puerto Rico Datum, 1940 adjustment.

Altitude, as used in this report, refers to distance above the vertical datum.

*Transmissivity: The standard unit for transmissivity is cubic foot per day per square foot times foot of aquifer thickness $\left[\left(\mathrm{ft}^{3} / \mathrm{d}\right) / \mathrm{ft}^{2}\right] \mathrm{ft}$. In this report, the mathematically reduced form, foot squared per day $\left(\mathrm{ft}^{2} / \mathrm{d}\right)$, is used for convenience.

Specific conductance is given in microsiemens per centimeter at 25 degrees Celsius $\left(\mu \mathrm{S} / \mathrm{cm}\right.$ at $\left.25^{\circ} \mathrm{C}\right)$.

Concentrations of chemical constituents in water are given either in milligrams per liter (mg/L) or micrograms per liter ( $\mu \mathrm{g} / \mathrm{L})$.

\section{Abbreviations}

$\begin{array}{ll}\text { DAR } & \text { Deethylatrazine to atrazine ratio } \\ \text { DEA } & \text { Deethylatrazine } \\ \text { EPTC } & \text { S-ethyl-dipropyl-thiocarbamate } \\ \text { GUS } & \text { Groundwater ubiquity score } \\ \text { GPS } & \text { Global positioning system } \\ \text { MCL } & \text { Maximum contaminant level } \\ \text { MDL } & \text { Method detection level } \\ \text { MRL } & \text { Method reporting level }\end{array}$

PRASA Puerto Rico Aqueduct and Sewer Authority

PRDNER Puerto Rico Department of Natural and Environmental Resources

USGS U.S. Geological Survey 



\title{
Evaluation of Groundwater Quality and Selected Hydrologic Conditions in the South Coast Aquifer, Santa Isabel Area, Puerto Rico, 2008-09
}

\author{
By José M. Rodríguez
}

\begin{abstract}
An evaluation to define groundwater-quality conditions, with emphasis on the distribution of nitrate concentration, to identify potential sources leading to elevated nitrate concentrations and to estimate the nitrate loads from major sources, was conducted by the U.S. Geological Survey in the South Coast aquifer, Santa Isabel area, between January 2008 and May 2009. The study area covers approximately 5,800 hectares of the south coastal plain of Puerto Rico and 470 hectares in the foothills within the municipality of Santa Isabel. Agriculture is the principal land use in the area and includes the cultivation of diverse truck-farm crops, bioengineered crops for seed production, and until 2007, commercial poultry farms. Nitrate concentrations in groundwater near the center of the South Coast aquifer, Santa Isabel area, have increased from a range of 0.9 to 5.9 milligrams per liter as nitrogen in 1967 to a range of 1.3 to 23.6 milligrams per liter as nitrogen in 2008 . Analyses for the stable isotope ratios of nitrogen-15/ nitrogen-14 and oxygen-18/oxygen-16 in nitrate were used to infer the source of nitrate in the aquifer and in the foothills north of the coastal plain. Results obtained from the samples analyses of stable isotope ratios indicate that the high nitrate concentrations in the western and central parts of the study area were in the range typically associated with soil nitrogen.

Potential residual nitrogen loads from areas under cultivation were estimated for the principal crops in the area. The residual load estimates ranged from 25 kilograms of nitrogen per hectare per year in tomato crops to 228 kilograms of nitrogen per hectare per year in banana crops. The potential nitrogen loads from two communities without sanitary sewer systems were estimated to be approximately 101 and 195 kilograms of nitrogen per hectare per year, respectively.

Groundwater withdrawals in the South Coast aquifer, Santa Isabel area were estimated to be
\end{abstract}

approximately 64,400 cubic meters per day, of which 52 percent were for agriculture, and 48 percent were for public-water supply. Groundwater flow in the study area was primarily southward from the north towards two cones of depression present within the central and southwestern parts of the study area. The presence of those cones of depression may contribute to an increase in nitrate concentrations within a total area of about 1,300 hectares owing to the recirculation of groundwater with elevated nitrate concentrations that is used to irrigate cultivated lands.

\section{Introduction}

The source of drinking water in the Santa Isabel and Coamo areas of Puerto Rico (Molina and GómezGómez, 2008) is the South Coast aquifer (hereafter referred to as the aquifer), which supplies about 30,700 cubic meters per day $\left(\mathrm{m}^{3} / \mathrm{d}\right)$ to Puerto Rico Aqueduct and Sewer Authority (PRASA) public-supply wells. In addition, approximately 45 wells provide an estimated $33,700 \mathrm{~m}^{3} / \mathrm{d}$ of groundwater to irrigate crops in the area. In 1967, baseline nitrate concentrations in groundwater throughout most of the aquifer were generally less than 6 milligrams per liter $(\mathrm{mg} / \mathrm{L})$ as nitrogen in collected water samples (U.S. Geological Survey, 2012). In 2007, elevated nitrate concentrations were detected in the aquifer, near Santa Isabel and the foothills north of the coastal plain at Santa Isabel as part of a regional groundwater-quality assessment conducted by the U.S. Geological Survey (USGS) during 2007 (Rodríguez and Gómez-Gómez, 2008). The increase in nitrate concentrations has been of concern to local government agencies because of its potential effect on public supply. 
To address public-supply concerns, the U.S. Geological Survey (USGS), in cooperation with the Puerto Rico Department of Natural and Environmental Resources (PRDNER), evaluated groundwater quality in the aquifer near the Santa Isabel area between January 2008 and May 2009. The objectives of the study were to (1) define the groundwater-quality conditions of the aquifer, with emphasis on the distribution of nitrate concentrations; (2) identify potential sources leading to elevated nitrate concentrations; (3) estimate the nitrate loads from major sources identified; and

(4) estimate the groundwater withdrawals by principaluse categories in the area. Results of this study will be used by Commonwealth of Puerto Rico and Federal agencies in developing strategies that can result in containment of high nitrate groundwater to minimize degradation of fresh groundwater in the aquifer.

\section{Purpose and Scope}

The purpose of this report is to evaluate the groundwater-quality and selected hydrologic conditions in the aquifer near the Santa Isabel area and the Gabia area in the foothills during 2008-09 using data obtained from 74 groundwater wells and 5 surface-water sites. Water-quality data collected during the study included analyses for nutrients, pesticides, and the stable isotope ratios oxygen-18/16 and nitrogen-15/14 in nitrate. As part of the study, data were also obtained to define groundwater withdrawals by major use categories, delineate the water table, determine land use patterns, and estimate potential nitrogen loads to the aquifer from fertilizer application, disposal of animal wastes, and domestic septic wastes from unsewered communities.

\section{Description of the Study Area}

The study area is located along the south coastal plain of Puerto Rico (fig. 1). The study area includes approximately 5,800 hectares (ha) that overlie the aquifer and approximately 470 ha in the foothills to the north of the coastal plain that overly volcanic rocks. The aquifer in the Santa Isabel area is composed of fan-delta and alluvial deposits. The study area is bordered by the Río Descalabrado to the west, the Río Jueyes (an intermittent stream) to the east, the hydrologic divide formed by the foothills to the north, and the Caribbean Sea to the south (figs. 1 and 2).

The study area is located within the municipality of Santa Isabel, which has historically been one of the most intensively used agricultural areas along the south coastal plain (fig. 1). Sugarcane cultivation was the principal land use at the Santa Isabel area until the 1970s, when sugarcane was gradually replaced by vegetable, fruit, row crops, and seed production crops.
This transition resulted in a parallel shift from furrow irrigation to micro-drip irrigation. By the early 1990s, all of the cultivated areas were using micro-drip irrigation.

\section{Climate}

The south coastal plain is warmer and drier than the other parts of Puerto Rico because of the rain-shadow effect the east-west trending Cordillera Central mountain range has on the prevailing northeast trade winds. The mean annual rainfall in the coastal plain near the study area from 1955 to 2006 was 809 millimeters (mm) (Santa Isabel 2 ENE National Weather Service station 668940 , figs. 1 and 2), as compared to $2,114 \mathrm{~mm}$ at 652 meters $(\mathrm{m})$ altitude in the Cordillera Central (Aceituna National Weather Service station 660040, fig. 1), and 1,346 $\mathrm{mm}$ on the northern coast in San Juan (National Weather Service station 668812, fig. 1). The monthly mean rainfall at the Santa Isabel 2 ENE weather station ranged from 15.5 to $179 \mathrm{~mm}$ during its 1955-2006 period of record (fig. 3).

A relatively dry season lasts from December to April, with February being the driest month, and a relatively wet season lasts from August to November, with October being the wettest month (fig. 3). The study was conducted during a period in which 11 of the 17 months of the study received below-average rainfall. The mean annual temperature along the south coastal plain is approximately 3 to $5^{\circ} \mathrm{C}$ higher than in the mountains. Monthly mean maximum temperatures at the Aguirre Central weather station, about 19 kilometers $(\mathrm{km})$ east of the urban center of Santa Isabel, ranged from $29.7^{\circ} \mathrm{C}$ in February to $32.2^{\circ} \mathrm{C}$ in August (from 1955 to 2006).

\section{Physiographic Features}

The south coastal plain is characterized by a parched vegetative cover, except in areas under irrigation or near intermittently flowing streams. Altitudes in the coastal plain range from 0 to approximately $40 \mathrm{~m}$ above mean sea level. The east-central part of the coastal plain at Santa Isabel is separated from the Caribbean Sea by a zone of mangroves, swampland, and tidal flats. The hills to the north also form a hydrologic barrier that partially surrounds the Gabia area basin. The maximum altitude of the hills bordering the Gabia basin is about $200 \mathrm{~m}$ above mean sea level. The altitude of the basin floor in the Gabia area ranges from approximately $55 \mathrm{~m}$ above mean sea level in the inland part of the coastal plain to $140 \mathrm{~m}$ above mean sea level in the northern part. 

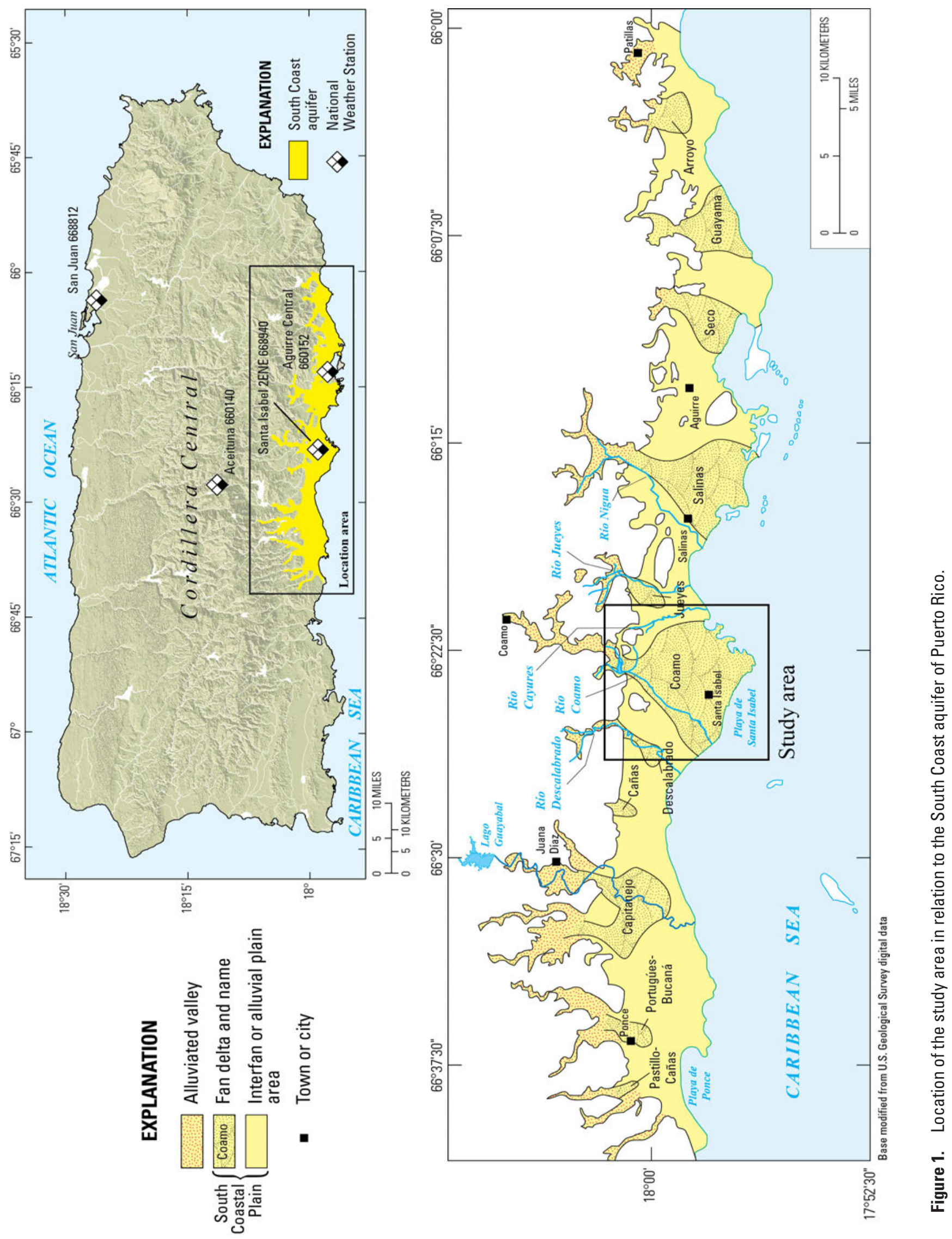


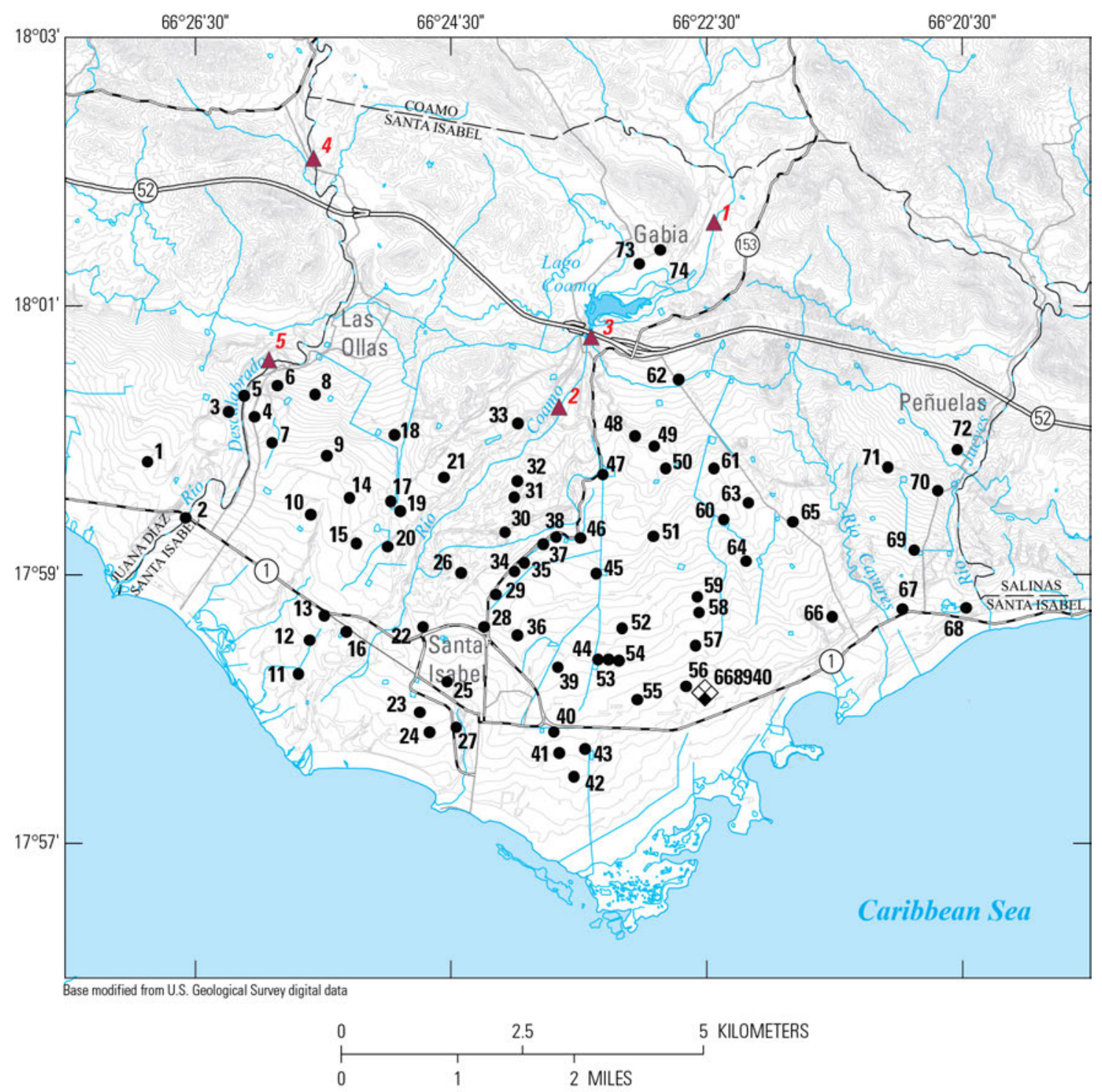

\section{EXPLANATION}

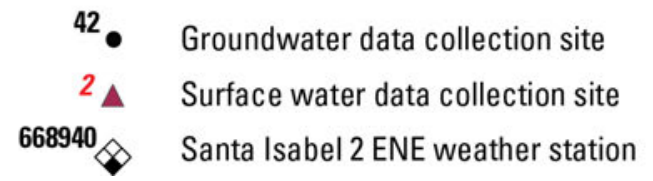

Figure 2. Location of data collection sites in the Santa Isabel area, Puerto Rico, 2008-09. 


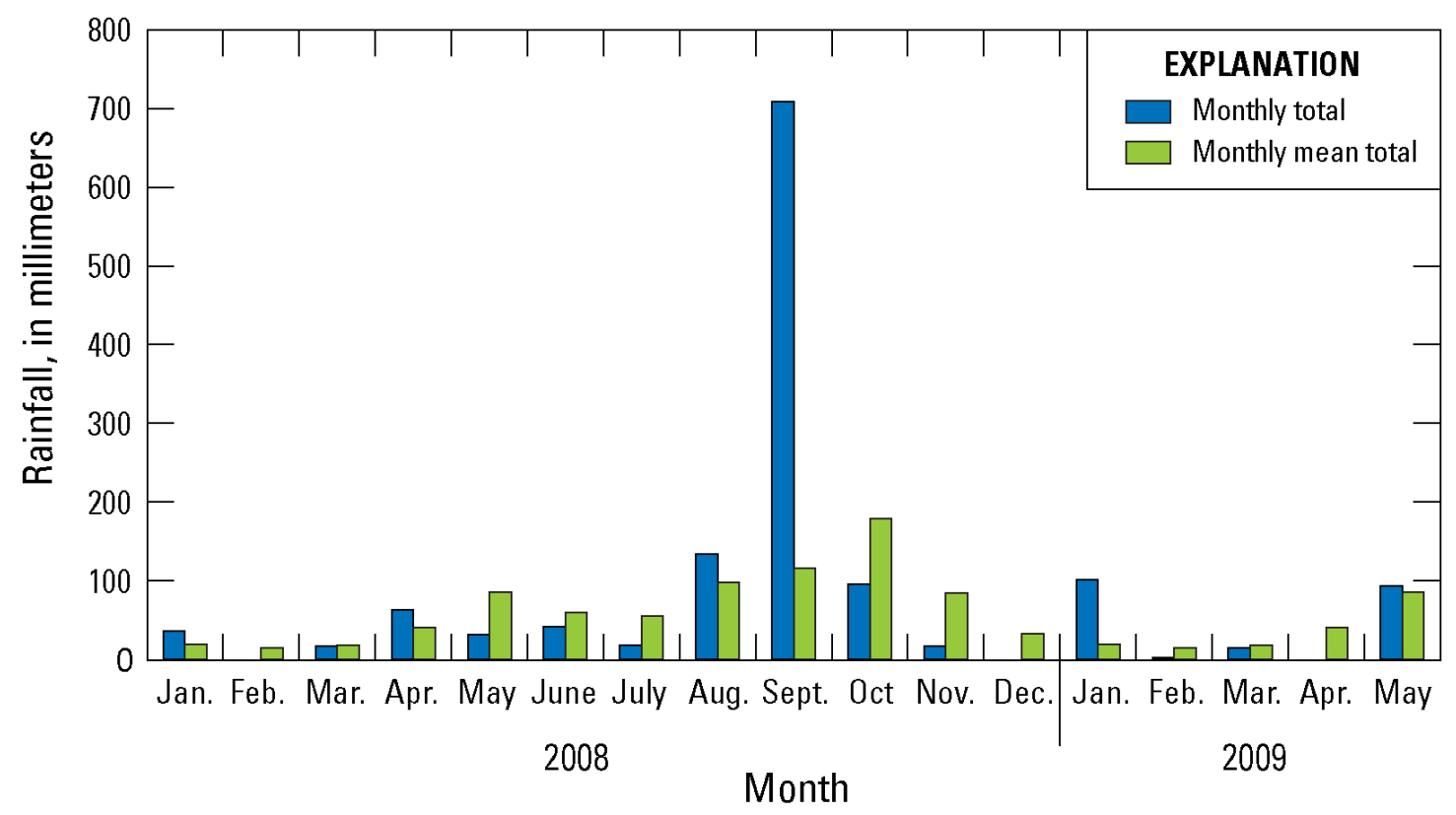

Figure 3. Distribution of monthly total (2008-09) and historical monthly mean total (1955-2009) rainfall at the Santa Isabel 2ENE National Weather Service station (668940), Santa Isabel, Puerto Rico.

\section{Land Use}

Land use in the study area during 2007 included agriculture, urban, and industrial uses (fig. 4). Active agricultural land use occupied approximately 56 percent of the study area, urban use occupied about 10 percent, and industrial use occupied less than 1 percent. The remaining 34 percent of the study area consisted of uncultivated land - primarily grassland, scrub, and shrub. Major crops grown within the coastal plain include corn, tomato, bananas, mangos, and vegetables. Tomato, corn, and vegetable farms occupy approximately 16, 18, and 22 percent, respectively, of the actively used agricultural land.

In the Gabia area, which comprises approximately 470 ha in the foothills north of the coastal plain, about 56 percent is dedicated to poultry farms. Forty poultry farms were in operation until 2007 and occupied approximately 267 ha.

\section{Methods of Investigation}

As part of this study, the status of selected wells within the study area was revised to update the USGS Ground-Water Site Inventory database (fig. 2, table 1). The location of each well was confirmed using a global positioning system (GPS) unit, and groundwater-withdrawal rates were obtained from periodic water-meter readings. General land-use data were obtained from 2007 aerial photographs and from field visits and interviews with farmers in the study area. Information about fertilizer application rates and crop types were obtained by interviewing farmers and during field reconnaissance.

Groundwater levels were measured in 47 wells from March 31 to April 3, 2008, and used to prepare a water-table map of the aquifer within the study area. The map was used to delineate the general direction of groundwater flow and evaluate the sources of nitrate affecting the sampled wells.

Groundwater samples were collected from 28 wells, and surface-water samples were collected from 3 streamflow measurement sites in May 2008. In addition, 2 wells and 3 surface-water sites were sampled on April 16 and April 17, 2009. The collected samples were analyzed for nutrients (organic nitrogen, ammonia, nitrate, nitrite, and phosphorus), and stable isotopes ratios of oxygen- $18 / 16\left({ }^{18} \mathrm{O} /{ }^{16} \mathrm{O}\right)$ and nitrogen- $15 / 14$ $\left({ }^{15} \mathrm{~N} /{ }^{14} \mathrm{~N}\right)$ in nitrate; samples from 10 selected wells were also analyzed for pesticides. Temperature, specific conductance, and $\mathrm{pH}$ were determined in the field at all sites sampled. Groundwater samples were collected from active production wells as near as possible to the pump discharge location and before water entry into the storage tanks. Surface-water samples were collected near the middle of stream cross sections. Field measurements and samples for laboratory analyses were collected, processed, and preserved according to procedures described by the National Field Manual for 


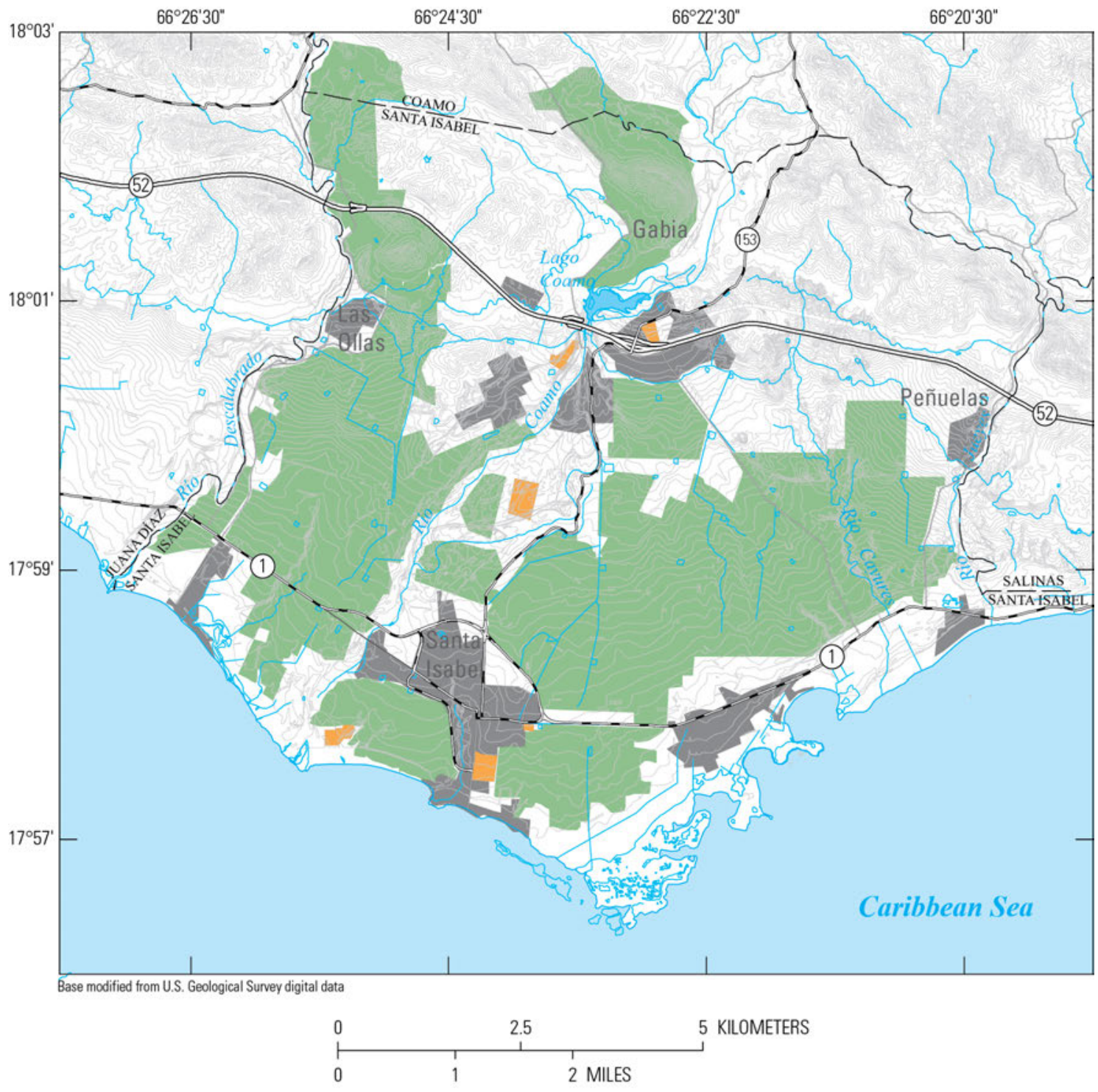

\section{EXPLANATION}

Agriculture

Urban

Industrial

Figure 4. General land use in the Santa Isabel area, Puerto Rico, 2008-09. 
Table 1. Information for selected wells in the Santa Isabel area, Puerto Rico.

[nd, no data; E, estimated value]

\begin{tabular}{|c|c|c|c|c|}
\hline \multirow[b]{2}{*}{$\begin{array}{l}\text { Number on } \\
\text { figure } 2\end{array}$} & \multirow{2}{*}{$\begin{array}{l}\text { Depth of well, } \\
\text { in meters } \\
\text { below land } \\
\text { surface }\end{array}$} & \multirow{2}{*}{$\begin{array}{l}\text { Screened interval, in } \\
\text { meters below land } \\
\text { surface }\end{array}$} & \multicolumn{2}{|c|}{ Groundwater withdrawals } \\
\hline & & & $\begin{array}{c}\text { Cubic meters } \\
\text { per day }\end{array}$ & $\begin{array}{c}\text { Million gallons } \\
\text { per day }\end{array}$ \\
\hline 1 & 64.0 & $0-64.0$ & nd & nd \\
\hline 2 & nd & nd & 1,060 & 0.28 \\
\hline 3 & 103 & nd & 0 & 0.00 \\
\hline 4 & 57.0 & $0-57.0$ & 0 & 0.00 \\
\hline 5 & nd & nd & 1,703 & 0.45 \\
\hline 6 & 39.9 & $4.9-20.7,29.2-39.9$ & 0 & 0.00 \\
\hline 7 & 72.2 & $0-9.1,12.8-72.2$ & 833 & 0.22 \\
\hline 8 & 72.8 & $0-72.8$ & 492 & 0.13 \\
\hline 9 & 62.8 & $7.3-62.8$ & 76 & 0.02 \\
\hline 10 & nd & nd & 492 & $0.13 \mathrm{E}$ \\
\hline 11 & 24.4 & nd & 0 & 0.00 \\
\hline 12 & 48.8 & $12.2-48.8$ & 871 & 0.23 \\
\hline 13 & nd & nd & 530 & 0.14 \\
\hline 14 & 67.7 & $7.3-67.4$ & 1,249 & 0.33 \\
\hline 15 & nd & nd & 909 & 0.24 \\
\hline 16 & 67.0 & $0-67.0$ & 681 & 0.18 \\
\hline 17 & 57.3 & $4.9-57.3$ & 606 & 0.16 \\
\hline 18 & nd & nd & 909 & 0.24 \\
\hline 19 & nd & nd & 416 & $0.11 \mathrm{E}$ \\
\hline 20 & 73.1 & $0-73.1$ & 1,249 & 0.33 \\
\hline 21 & nd & nd & 454 & $0.12 \mathrm{E}$ \\
\hline 22 & nd & nd & 0 & 0.00 \\
\hline 23 & 51.8 & $0-51.8$ & 1,401 & $0.37 \mathrm{E}$ \\
\hline 24 & 61.0 & $59.4-61.0$ & 0 & 0.00 \\
\hline 25 & nd & nd & 1,590 & 0.42 \\
\hline 26 & nd & nd & 1,022 & 0.27 \\
\hline 27 & 76.2 & nd & 1,401 & $0.37 \mathrm{E}$ \\
\hline 28 & nd & nd & 1,287 & 0.34 \\
\hline 29 & nd & nd & 4,618 & 1.22 \\
\hline 30 & nd & nd & 76 & 0.02 \\
\hline 31 & nd & nd & 76 & 0.02 \\
\hline 32 & nd & nd & 76 & 0.02 \\
\hline 33 & 33.5 & $0-33.5$ & 946 & 0.25 \\
\hline 34 & 61.6 & nd & 0 & 0.00 \\
\hline 35 & nd & nd & 4,315 & 1.14 \\
\hline 36 & nd & nd & 1,438 & $0.38 \mathrm{E}$ \\
\hline 37 & 54.9 & nd & 6,170 & 1.63 \\
\hline 38 & 59.4 & $0-59.4$ & 492 & 0.13 \\
\hline 39 & 65.8 & $0-6508$ & 530 & 0.14 \\
\hline 40 & 46.3 & $6.1-46.3$ & 0 & 0.00 \\
\hline 41 & nd & nd & 946 & 0.25 \\
\hline
\end{tabular}


Table 1. Information for selected wells in the Santa Isabel area, Puerto Rico._Continued

\begin{tabular}{|c|c|c|c|c|}
\hline \multirow[b]{2}{*}{$\begin{array}{c}\text { Number on } \\
\text { figure } 2\end{array}$} & \multirow{2}{*}{$\begin{array}{l}\text { Depth of well, } \\
\text { in meters } \\
\text { below land } \\
\text { surface }\end{array}$} & \multirow{2}{*}{$\begin{array}{l}\text { Screened interval, in } \\
\text { meters below land } \\
\text { surface }\end{array}$} & \multicolumn{2}{|c|}{ Groundwater withdrawals } \\
\hline & & & $\begin{array}{l}\text { Cubic meters } \\
\text { per day }\end{array}$ & $\begin{array}{c}\text { Million gallons } \\
\text { per day }\end{array}$ \\
\hline 42 & 21.3 & nd & 0 & 0.00 \\
\hline 43 & nd & nd & 0 & 0.00 \\
\hline 44 & 34.1 & nd & 0 & 0.00 \\
\hline 45 & 57.9 & $0-57.9$ & 1,211 & 0.32 \\
\hline 46 & 61.0 & nd & 5,754 & 1.52 \\
\hline 47 & 61.0 & nd & 3,028 & 0.80 \\
\hline 48 & nd & nd & 757 & 0.20 \\
\hline 49 & nd & nd & 379 & 0.10 \\
\hline 50 & 63.1 & $12.2-63.1$ & 492 & 0.13 \\
\hline 51 & 32.9 & $0-32.9$ & 1,173 & $0.31 \mathrm{E}$ \\
\hline 52 & nd & nd & 1,817 & $0.48 \mathrm{E}$ \\
\hline 53 & nd & nd & 1,249 & 0.33 \\
\hline 54 & nd & nd & 1,022 & 0.27 \\
\hline 55 & nd & nd & 719 & 0.19 \\
\hline 56 & nd & nd & 0 & 0.00 \\
\hline 57 & nd & nd & 1,022 & 0.27 \\
\hline 58 & nd & nd & 0 & 0.00 \\
\hline 59 & nd & nd & 795 & 0.21 \\
\hline 60 & nd & nd & 1,173 & $0.31 \mathrm{E}$ \\
\hline 61 & 56.4 & $21.6-56.4$ & 114 & 0.03 \\
\hline 62 & nd & nd & 0 & 0.00 \\
\hline 63 & nd & nd & 568 & $0.15 \mathrm{E}$ \\
\hline 64 & 64.0 & nd & 946 & $0.25 \mathrm{E}$ \\
\hline 65 & nd & nd & 0 & 0.00 \\
\hline 66 & nd & nd & 795 & $0.21 \mathrm{E}$ \\
\hline 67 & nd & nd & 0 & 0.00 \\
\hline 68 & nd & nd & 0 & 0.00 \\
\hline 69 & 47.5 & $0-47.5$ & 681 & $0.18 \mathrm{E}$ \\
\hline 70 & nd & nd & 416 & 0.11 \\
\hline 71 & nd & nd & 530 & $0.14 \mathrm{E}$ \\
\hline 72 & 35.0 & $16.8-35.0$ & 0 & 0.00 \\
\hline 73 & nd & nd & 757 & 0.20 \\
\hline 74 & 45.7 & nd & 0 & 0.00 \\
\hline \multicolumn{3}{|c|}{ Total groundwater withdrawal } & 64,311 & 16.99 \\
\hline
\end{tabular}


the Collection of Water-Quality Data (U.S. Geological Survey, variously dated). Samples for nutrients and pesticides were analyzed at the USGS National Water Quality Laboratory in Denver, Colorado.

Analyses of oxygen and nitrogen isotopes in nitrate were performed in the USGS Stable Isotope Laboratory in Reston, Virginia. Samples collected for this analysis were passed through a 0.20 -micrometer filter into 125 -milliliter $(\mathrm{mL})$ plastic bottles and chilled at $4^{\circ} \mathrm{C}$. Results for oxygen isotopes are reported as delta units $(\delta)$ per mil relative to the Vienna Standard Mean Ocean Water reference water and normalized on a scale such that Standard Antarctic Precipitation reference water is -55.5 per mil (Coplen, 1988, 1994).

Water samples for nitrogen isotopes were analyzed by bacterial conversion of nitrate to nitrous oxide and subsequent measurement on a continuous flow isotope ratio mass spectrometer (Sigman and others, 2001; Casciotti and others, 2002; Revesz and Casciotti, 2003). Nitrogen isotope ratios are reported as delta units $(\delta)$ in per mil relative to $\mathrm{N}_{2}$ in air (Mariotti, 1983).

The concentrations of ${ }^{18} \mathrm{O}$, and ${ }^{15} \mathrm{~N}$ in water are defined by the expression:

$$
\delta(\%)=[(\text { R sample } / \mathrm{R} \text { standard })-1] \times 1,000
$$

where

$$
\begin{array}{ll}
\delta(\%) & \text { is delta units in per mil, and } \\
R & \text { corresponds to the ratios of }{ }^{18} \mathrm{O} /{ }^{16} \mathrm{O} \text { or }{ }^{15} \mathrm{~N} /{ }^{14} \mathrm{~N}
\end{array}
$$

\section{Hydrologic Setting}

The study area lies within the areal boundaries of the South Coast aquifer and extends from the coast to the bedrock hills north of the coastal plain. Fan delta and alluvial deposits constitute the aquifer in the Santa Isabel area (fig. 5); these deposits exceed $300 \mathrm{~m}$ in thickness along the coast and thin to approximately $18 \mathrm{~m}$ near the bedrock hills (Renken and others, 2002).

The estimated hydraulic conductivity of the fan delta deposits in the Santa Isabel area ranges from less than 1 meter per day $(\mathrm{m} / \mathrm{d})$ to approximately 80 m/d (Bennett, 1976; Renken and others, 2002); values are greatest in the thickest part of the aquifer (Renken and others, 2002). The depth to water during 2008 was between 3 and $35 \mathrm{~m}$ below land surface, which represents a range in groundwater altitude from -3.5 to $39.2 \mathrm{~m}$ relative to mean sea level. Yields from wells used for agriculture and public supply in the study area ranged from 22 to 126 liters per second $(\mathrm{L} / \mathrm{s})$.

Swamp and beach deposits compose the southeastern boundary of the coastal plain in the study area and a bedrock hill composed of the Ponce
Limestone crops out in the northwestern part of the study area (fig. 5). Swamp deposits consist of unconsolidated clay, silt, and organic material (Glover and others, 1977) and beach deposits consist of unconsolidated sand, gravel, and cobbles (Glover, 1961). The bedrock outcrop was described by Glover and Mattson (1973) as consisting of limestone and sandstone formations.

The hills near the Gabia area consist primarily of Tertiary and Cretaceous volcanic rocks (Glover and Mattson, 1973). Yields from wells in the Gabia area range from 1.3 to $2.5 \mathrm{~L} / \mathrm{s}$.

\section{Groundwater Conditions}

Groundwater in the study area generally flows southward toward two cones of depression, as determined from the configuration of the water table in the area. Contours of equal groundwater altitude were delineated using water-level measurements obtained between March 31 and April 3, 2008 (fig. 6). The cones of depression are located in the northern central and the southwestern parts of the study area and were created by local groundwater withdrawals from irrigation and public-supply wells. Measured water levels were below mean sea level over most of the Santa Isabel area. A $\mathrm{V}$-shaped water-table contour in the southeastern part of the study area indicates a potential zone of freshwaterseawater mixing.

The water-table configuration in the aquifer determined from the data collected during March-April 2008 was compared with a configuration determined from data collected in March 1986 (Rodríguez-Del Río and Gómez-Gómez, 1990). The comparison of these water-table configurations indicates that the groundwater levels in the aquifer decreased by an average of about $4 \mathrm{~m}$ between March 1986 and March-April 2008.

The historical data obtained from observation well Alomar 1 (number 44 in figs. 2 and 7), which is located in the central part of the study area, indicates a declining water-level trend from 1986 to 1994 , with a total decline of about $8 \mathrm{~m}$. Data collected from the same well during 1993-2008 indicate groundwater-level fluctuations were near or below mean sea level.

A study to evaluate the effects of aquifer development and changes in irrigation practices on groundwater availability from 1987 to 2003 in the Santa Isabel area was conducted by Kuniansky and others (2003). This study, which included the development of digital groundwater flow model, indicated that the main effects of the changes in agricultural practices were reductions in recharge to the aquifer and in total irrigation withdrawals. The study also determined that groundwater withdrawals for public supply wells steadily increased from 7,580 m²/d in 1973 


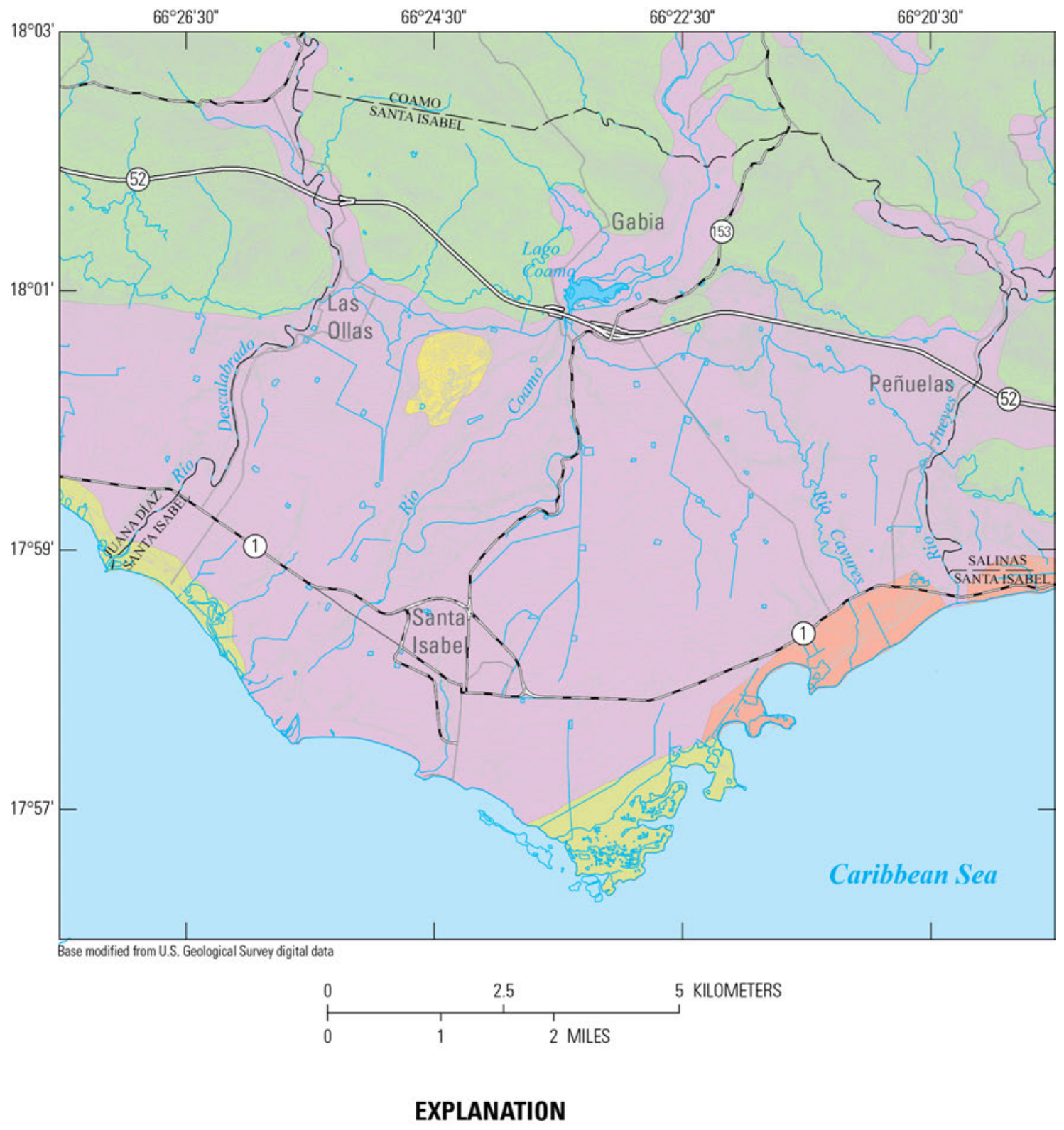

Marsh and swamp deposits

Beach deposits

Alluvium

Volcanic and sedimentary rocks

Ponce limestone

Figure 5. Surficial geology in the Santa Isabel area, Puerto Rico. 


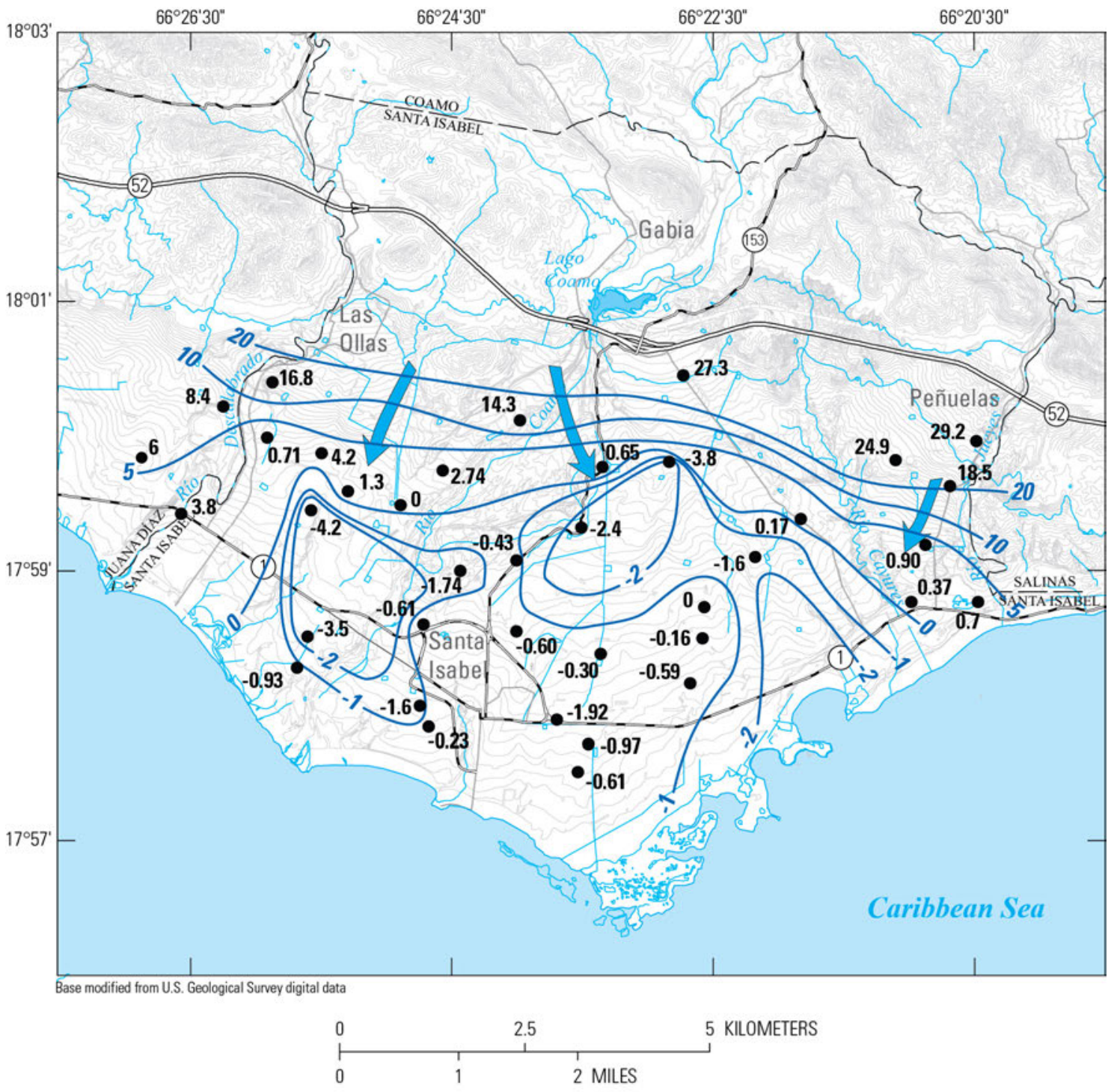

\section{EXPLANATION}

— - W Water-table contour-Shows altitude at which water level would have stood in tightly cased well. Countour interval variable in meters. Datum mean sea level

General direction of groundwater flow

- -0.61 Groundwater level data control point-Number is water level, in meters referenced to local mean sea level

Figure 6. Water-table configuration in the South Coast aquifer, Santa Isabel area, Puerto Rico, March 31April 3, 2008. 


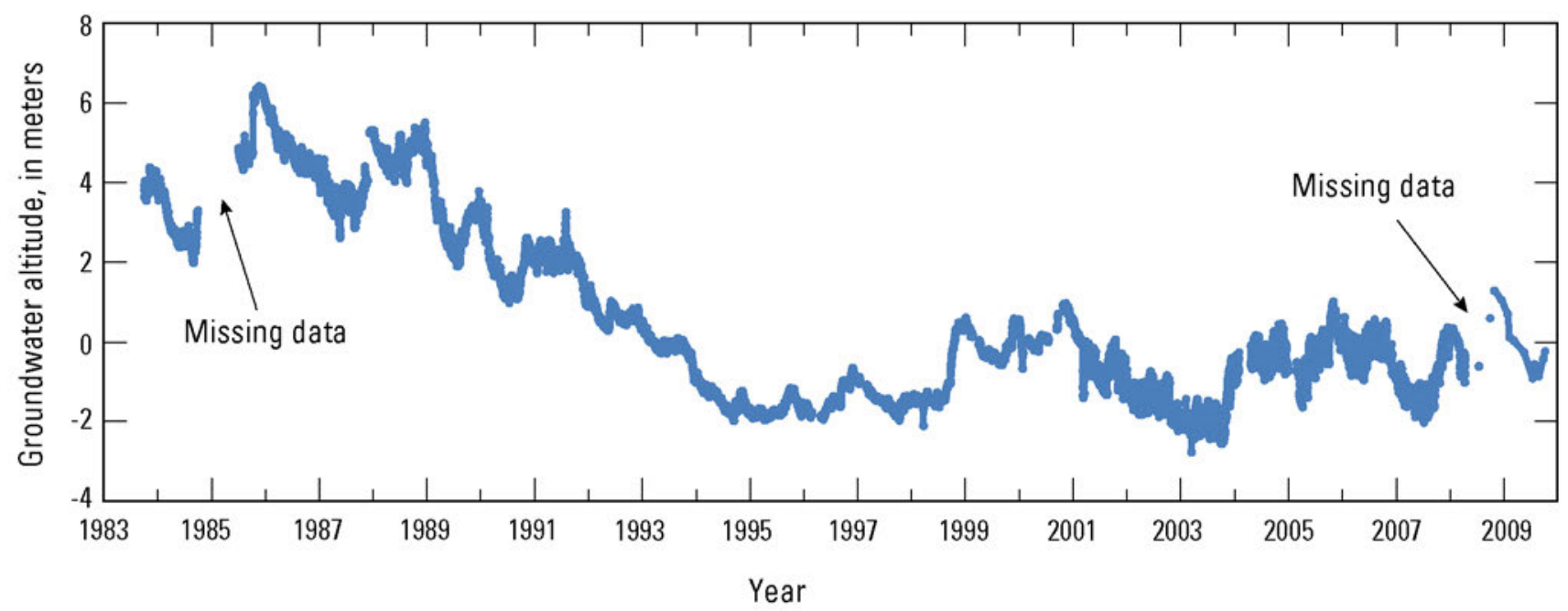

Figure 7. Water levels at site 44, observation well Alomar 1 (175829066232200), Santa Isabel, Puerto Rico.

to about $26,530 \mathrm{~m}^{3} / \mathrm{d}$ in 2003 . In addition, the reduction of recharge lowered the water table below mean sea level over most of the Santa Isabel area; this process reversed the natural groundwater gradient along the coast and caused saltwater intrusion into the aquifer.

Total groundwater withdrawals from the aquifer in the coastal plain section of the study area were estimated during 2008 to be about $64,300 \mathrm{~m}^{3} / \mathrm{d}$ (table 1), consisting of $32,700 \mathrm{~m}^{3} / \mathrm{d}$ for irrigation and $31,600 \mathrm{~m}^{3} / \mathrm{d}$ for public supply. In the Gabia area, groundwater withdrawals during 2008 were negligible because poultry farms had ceased operations by that time.

\section{Water Quality}

Water samples were collected within the study area during May 2008 and April 2009. Data were collected from a total of 30 groundwater wells and 5 surface-water sites (tables 2 and 3). Data were collected in April 2009 to include 2 wells and 2 surface-water sites that were not sampled during May 2008. All samples were analyzed for nutrients and stable isotopes of nitrogen and oxygen in nitrate. Samples from 10 wells were analyzed for pesticides. Field measurements of specific conductance were used to estimate dissolved-solids concentrations.

\section{Specific Conductance and Dissolved Solids}

Specific conductance data collected during the May 2008 and April 2009 are shown on figure 8. As ion concentrations increase, the conductance of a solution increases; therefore, the conductance measurement provides an indication of the ion concentration (Hem, 1989). This relation between ion concentration and specific conductance permits dissolved-solids concentrations to be estimated using specific conductance determinations. Specific conductance and dissolved-solids concentration are linearly related by the equation

$$
K A=S
$$

where

$$
\begin{gathered}
\mathrm{K} \text { is the specific conductance, } \\
\mathrm{A} \text { is the slope of the linear relation, and } \\
\mathrm{S} \text { is the approximate total dissolved-solids } \\
\text { concentration (Hem, 1985). }
\end{gathered}
$$

Specific conductance and dissolved-solids data collected for the South Coast aquifer by Díaz (1979) and Rodríguez and Gómez-Gómez (2008) indicate that the constant $\mathrm{A}$ is about 0.60 for the range of conductance data shown on figure 8 . Groundwater having a specific conductance of less than 850 microsiemens per centimeter $(\mu \mathrm{S} / \mathrm{cm})$ at $25^{\circ} \mathrm{C}$, which represents a dissolved-solids concentration of less than $500 \mathrm{mg} / \mathrm{L}$, is preferred for public water supply. The U.S. Environmental Protection Agency has established a drinking water secondary maximum contaminant level (MCL) for dissolved solids of $500 \mathrm{mg} / \mathrm{L}$ (U.S. Environmental Protection Agency, 2009).

Irrigation water with specific conductance in the range of 750 to $2,250 \mu \mathrm{S} / \mathrm{cm}$ is considered a high salinity hazard for crops, according to the U.S. Department of Agriculture irrigation water classification (Richards, 1954). Irrigation water with specific conductance above $2,250 \mu \mathrm{S} / \mathrm{cm}$ is considered a very high salinity hazard 
Table 2. Nutrient concentrations and delta nitrogen-15 and delta oxygen-18 of nitrate in groundwater samples collected from selected wells in the Santa Isabel area, Puerto Rico, 2008-09.

[Nutrient concentrations are given in milligrams per liter, unless otherwise noted; $\mu \mathrm{S} / \mathrm{cm}$, microsiemens per centimeter at 25 degrees Celsius; <, less than the analytical detection limit; $\delta^{15} \mathrm{~N}$, ratio of nitrogen-15/ nitrogen-14; $\delta^{18} \mathrm{O}$, ratio of oxygen-18/ oxygen-16]

\begin{tabular}{|c|c|c|c|c|c|c|c|c|c|c|c|c|c|}
\hline $\begin{array}{l}\text { Num- } \\
\text { ber on } \\
\text { figure } 2\end{array}$ & $\begin{array}{c}\text { Date of } \\
\text { sample } \\
\text { collection }\end{array}$ & $\mathrm{pH}$ & $\begin{array}{c}\text { Specific } \\
\text { Conduc- } \\
\text { tance } \\
\text { ( } \mathrm{s} / \mathrm{cm})\end{array}$ & $\begin{array}{c}\text { Tem- } \\
\text { pera- } \\
\text { ture } \\
\text { (degrees } \\
\text { Celsius) }\end{array}$ & $\begin{array}{c}\text { Nitrate } \\
\text { plus } \\
\text { nitrite }\end{array}$ & Nitrite & Nitrate & $\begin{array}{l}\text { Ammo- } \\
\text { nia plus } \\
\text { organic } \\
\text { nitrogen }\end{array}$ & $\begin{array}{c}\text { Ammo- } \\
\text { nia }\end{array}$ & $\begin{array}{l}\text { Ortho- } \\
\text { phos- } \\
\text { phate }\end{array}$ & $\begin{array}{l}\text { Phos- } \\
\text { phorus }\end{array}$ & $\begin{array}{c}\delta^{15} \mathrm{~N} \text { in } \\
\text { nitrate } \\
\text { (per } \\
\text { mil) }\end{array}$ & $\begin{array}{c}\delta^{18} 0 \text { in } \\
\text { nitrate } \\
\text { (per mil) }\end{array}$ \\
\hline 8 & $4 / 16 / 2009$ & 7.6 & 1,110 & 27.8 & 14.9 & $<0.002$ & 14.9 & $<0.1$ & $<0.02$ & 0.044 & 0.031 & 7.4 & 5.91 \\
\hline 9 & $5 / 6 / 2008$ & 7.5 & 1,230 & 28.5 & 19.02 & 0.002 & 19.02 & 0.152 & $<0.02$ & 0.054 & 0.045 & 5.56 & 7.47 \\
\hline 10 & $5 / 7 / 2008$ & 7.2 & 1,250 & 27.2 & 12.87 & 0.002 & 12.87 & 0.155 & $<0.02$ & 0.036 & 0.026 & 6.22 & 5.52 \\
\hline 13 & $5 / 6 / 2008$ & 7.4 & 1,030 & 27.6 & 16.04 & $<0.002$ & 16.04 & 0.149 & $<0.02$ & 0.030 & 0.029 & 6.36 & 7.03 \\
\hline 15 & $5 / 6 / 2008$ & 7.6 & 1,140 & 27.4 & 20.91 & 0.002 & 20.91 & 0.224 & 0.023 & 0.031 & 0.038 & 5.82 & 6.03 \\
\hline 18 & $5 / 6 / 2008$ & 7.2 & 1,860 & 28.0 & 11.44 & $<0.002$ & 11.44 & 0.144 & $<0.02$ & 0.050 & 0.042 & 7.60 & 7.43 \\
\hline 19 & $5 / 7 / 2008$ & 7.1 & 1,180 & 27.7 & 18.49 & $<0.002$ & 18.49 & 0.165 & $<0.02$ & 0.033 & 0.026 & 5.71 & 5.15 \\
\hline 21 & $5 / 7 / 2008$ & 7.5 & 1,150 & 27.3 & 12.44 & $<0.002$ & 12.44 & 0.099 & $<0.02$ & 0.038 & 0.028 & 6.08 & 4.74 \\
\hline 23 & $5 / 7 / 2008$ & 7.2 & 725 & 27.5 & 8.93 & 0.011 & 8.92 & 0.249 & 0.114 & 0.038 & 0.031 & 4.89 & 5.07 \\
\hline 26 & $5 / 5 / 2008$ & 7.3 & 787 & 27.9 & 6.91 & $<0.002$ & 6.91 & $<0.14$ & $<0.02$ & 0.033 & 0.032 & 6.01 & 6.69 \\
\hline 28 & $5 / 6 / 2008$ & 7.6 & 759 & 27.5 & 4.92 & $<0.002$ & 4.92 & 0.101 & $<0.02$ & 0.034 & 0.024 & 7.39 & 4.63 \\
\hline 31 & $5 / 9 / 2008$ & 7.7 & 640 & 28.3 & 1.30 & $<0.002$ & 1.30 & 0.082 & $<0.02$ & 0.034 & 0.021 & 14.55 & 8.25 \\
\hline 33 & $5 / 9 / 2008$ & 7.0 & 1,070 & 27.9 & 2.37 & $<0.002$ & 2.37 & 0.120 & $<0.02$ & 0.037 & 0.032 & 9.76 & 4.87 \\
\hline 35 & $5 / 8 / 2008$ & 7.5 & 770 & 27.9 & 5.38 & $<0.002$ & 5.38 & 0.299 & $<0.02$ & 0.036 & 0.028 & 10.30 & 5.52 \\
\hline 39 & $5 / 6 / 2008$ & 7.5 & 1,010 & 27.7 & 23.63 & $<0.002$ & 23.63 & 0.121 & $<0.02$ & 0.035 & 0.028 & 6.71 & 7.34 \\
\hline 41 & $5 / 5 / 2008$ & 7.4 & 1,120 & 27.9 & 10.76 & 0.005 & 10.76 & 0.085 & $<0.02$ & 0.032 & 0.036 & 9.17 & 8.92 \\
\hline 47 & $5 / 8 / 2008$ & 7.2 & 803 & 28.1 & 2.34 & $<0.002$ & 2.34 & 0.128 & $<0.02$ & 0.038 & 0.042 & 9.82 & 6.40 \\
\hline 49 & $5 / 5 / 2008$ & 7.1 & 808 & 27.9 & 2.99 & $<0.002$ & 2.99 & 0.140 & $<0.02$ & 0.046 & 0.043 & 8.65 & 6.14 \\
\hline 51 & $5 / 8 / 2008$ & 7.6 & 1,200 & 27.2 & 11.46 & $<0.002$ & 11.46 & 0.099 & $<0.02$ & 0.052 & 0.042 & 6.15 & 3.80 \\
\hline 52 & $5 / 8 / 2008$ & 7.4 & 1,020 & 27.4 & 14.22 & $<0.002$ & 14.22 & 0.098 & $<0.02$ & 0.031 & 0.027 & 5.26 & 4.52 \\
\hline 54 & $5 / 5 / 2008$ & 7.0 & 1,140 & 27.7 & 19.91 & $<0.002$ & 19.91 & 0.082 & $<0.02$ & 0.035 & $<0.04$ & 5.93 & 4.75 \\
\hline 55 & $5 / 5 / 2008$ & 7.3 & 940 & 27.6 & 6.32 & $<0.002$ & 6.32 & 0.127 & $<0.02$ & 0.032 & 0.030 & na & na \\
\hline 57 & $5 / 6 / 2008$ & 7.1 & 3,480 & 27.8 & 7.08 & $<0.002$ & 7.08 & 0.140 & $<0.02$ & 0.037 & 0.035 & 6.87 & 5.06 \\
\hline 63 & $5 / 8 / 2008$ & 7.1 & 1,090 & 27.2 & 10.20 & $<0.002$ & 10.20 & 0.145 & $<0.02$ & 0.045 & 0.038 & 5.79 & 3.78 \\
\hline 64 & $5 / 7 / 2008$ & 7.7 & 1,140 & 27.1 & 7.89 & $<0.002$ & 7.89 & 0.128 & $<0.02$ & 0.048 & 0.042 & 6.88 & 5.23 \\
\hline 66 & $5 / 7 / 2008$ & 7.0 & 1,140 & 27.2 & 7.53 & $<0.002$ & 7.53 & 0.142 & $<0.02$ & 0.040 & 0.031 & 7.30 & 6.56 \\
\hline 69 & $5 / 7 / 2008$ & 7.6 & 768 & 27.6 & 3.39 & $<0.002$ & 3.39 & 0.110 & $<0.02$ & 0.033 & 0.022 & 10.90 & 5.59 \\
\hline 71 & $5 / 8 / 2008$ & 7.4 & 1,060 & 27.9 & 10.40 & $<0.002$ & 10.40 & 0.116 & $<0.02$ & 0.030 & 0.020 & 11.50 & 4.95 \\
\hline 73 & $5 / 8 / 2008$ & 7.4 & 1,440 & 28.1 & 15.17 & $<0.002$ & 15.17 & 0.309 & $<0.02$ & 0.038 & 0.028 & 9.65 & 6.45 \\
\hline 74 & $4 / 16 / 2009$ & 7.1 & 967 & 27.7 & 5.49 & $<0.002$ & 5.49 & E0.06 & $<0.02$ & 0.046 & E0.038 & 11.58 & 6.90 \\
\hline
\end{tabular}


Table 3. Nutrient concentrations, delta nitrogen-15, and delta oxygen-18 of nitrate in surface-water samples collected from selected streams in the Santa Isabel area, Puerto Rico, 2008-09.

[Nutrient concentrations are given in milligrams per liter, unless otherwise noted; $\mu \mathrm{S} / \mathrm{cm}$, microsiemens per centimeter at 25 degrees Celsius; <, less than the analytical detection limit; $\delta^{15} \mathrm{~N}$, ratio of nitrogen- $15 /$ nitrogen- $14 ; \delta^{18} \mathrm{O}$, ratio of oxygen-18/ oxygen-16]

\begin{tabular}{|c|c|c|c|c|c|c|c|}
\hline $\begin{array}{l}\text { Number in } \\
\text { map }\end{array}$ & $\begin{array}{l}\text { USGS site } \\
\text { identifier }\end{array}$ & $\begin{array}{c}\text { Date of sample } \\
\text { collection }\end{array}$ & $\begin{array}{l}\text { Instantaneous } \\
\text { discharge (cubic } \\
\text { feet per second) }\end{array}$ & pH & $\begin{array}{c}\text { Specific } \\
\text { conductance } \\
(\mu \mathrm{S} / \mathrm{cm})\end{array}$ & $\begin{array}{c}\text { Temperature } \\
\text { (degrees } \\
\text { Celsius) }\end{array}$ & $\begin{array}{c}\text { Nitrate } \\
\text { plus nitrite, } \\
\text { dissolved }\end{array}$ \\
\hline \multirow[t]{2}{*}{1} & 50106830 & $5 / 15 / 2008$ & 6.1 & 8.3 & 690 & 28.2 & 0.52 \\
\hline & & $4 / 17 / 2009$ & 12 & 8.2 & 635 & 30.3 & 1.00 \\
\hline 2 & 50106910 & $5 / 15 / 2008$ & 2.1 & 8.2 & 607 & 33.6 & 0.42 \\
\hline 3 & 50111330 & $5 / 15 / 2008$ & 11 & 8.0 & 249 & 29.6 & 0.20 \\
\hline 4 & 50108200 & $4 / 17 / 2009$ & 1.2 & 8.0 & 845 & 26.5 & 1.99 \\
\hline 5 & 50108375 & $4 / 17 / 2009$ & 1.0 & 8.2 & 813 & 29.3 & 1.23 \\
\hline
\end{tabular}

Table 3. Nutrient concentrations, delta nitrogen-15, and delta oxygen-18 of nitrate in surface-water samples collected from selected streams in the Santa Isabel area, Puerto Ric0, 2008-09.-Continued

[Nutrient concentrations are given in milligrams per liter, unless otherwise noted; $\mu \mathrm{S} / \mathrm{cm}$, microsiemens per centimeter at 25 degrees Celsius; <, less than the analytical detection limit; $\delta^{15} \mathrm{~N}$, ratio of nitrogen-15/ nitrogen- $14 ; \delta^{18} \mathrm{O}$, ratio of oxygen-18/ oxygen-16]

\begin{tabular}{ccccccccc}
\hline $\begin{array}{c}\text { Number } \\
\text { in map }\end{array}$ & $\begin{array}{c}\text { Nitrite, } \\
\text { dissolved }\end{array}$ & $\begin{array}{c}\text { Nitrate, } \\
\text { dissolved }\end{array}$ & $\begin{array}{c}\text { Ammonia plus } \\
\text { organic nitrogen, } \\
\text { dissolved }\end{array}$ & $\begin{array}{c}\text { Ammonia, } \\
\text { dissolved }\end{array}$ & $\begin{array}{c}\text { Ortho- } \\
\text { phosphate, } \\
\text { dissolved }\end{array}$ & $\begin{array}{c}\text { Phosphorus, } \\
\text { total }\end{array}$ & $\begin{array}{c}\boldsymbol{\delta}^{\mathbf{1 5}} \mathbf{N} \text { in } \\
\text { nitrate } \\
\text { (Per mil) }\end{array}$ & $\begin{array}{c}\boldsymbol{\delta}^{\mathbf{1 8}} \mathbf{O} \text { in } \\
\text { nitrate } \\
\text { (Per mil) }\end{array}$ \\
\hline 1 & 0.007 & 0.51 & 0.400 & $<0.02$ & 0.109 & 0.111 & 17.60 & 9.43 \\
& 0.007 & 0.99 & 0.400 & $<0.02$ & 0.107 & 0.126 & 15.28 & 8.18 \\
2 & 0.042 & 0.38 & 0.700 & 0.105 & 0.110 & 0.151 & 13.96 & -2.40 \\
3 & 0.009 & 0.19 & 0.300 & 0.036 & 0.037 & 0.101 & 6.56 & -0.68 \\
4 & 0.008 & 1.98 & 0.300 & $<0.02$ & 0.071 & 0.086 & 15.71 & 9.02 \\
5 & 0.012 & 1.22 & 0.700 & $<0.02$ & 0.058 & 0.075 & 16.43 & 12.32 \\
\hline
\end{tabular}




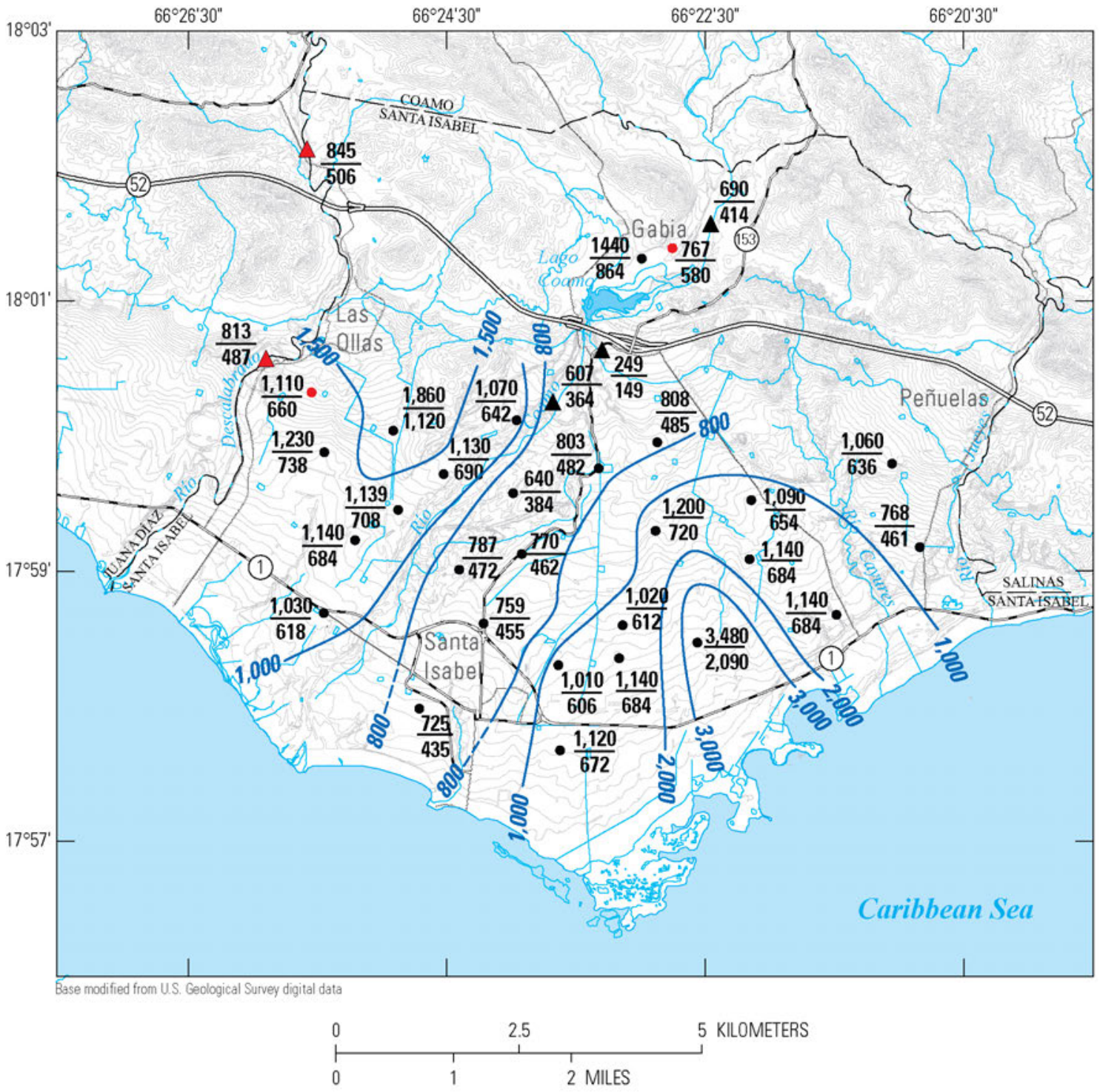

\section{EXPLANATION}

- $800---$ Line of equal specific conductance-Dashed where approximately located. Interval variable, in microsiemens at 25 degree Celsius.

1,120 Groundwater data control points-Top number is specific

- 672 conductance, in microsiemens per centimeter at 25 degree Celsius and bottom number is estimated dissolved solids concentration, in milligram per liter calculated by multiplying 0.6 times specific conductance. Control point in red color indicates data collected on April 2009.

813 Surface-water quality control points-Top number is specific conductance $\overline{487}$ in microsiemens per centimeter at 25 degree Celsius and bottom number is estimated dissolved solids concentration in milligram per liter calculated by multiplying 0.6 times specific conductance. Control point in red color indicates data collected on April 2009.

Figure 8. Specific conductance values in groundwater and surface water, Santa Isabel area, Puerto Rico, May 2008- April 2009. 
for crops. East of Río Coamo, groundwater specific conductance generally increases in the southeast direction from less than 700 to more than $3,000 \mu \mathrm{S} / \mathrm{cm}$. The maximum specific conductance values, which coincide with the inverted $\mathrm{v}$-shaped $-2 \mathrm{~m}$ contour on the water-table surface map (fig. 6), may be the result of lateral seawater intrusion. Samples collected in 2007 (Rodríguez, 2009) at well 57, which is located near the inverted $\mathrm{v}$-shaped contour, indicated that the chemical characteristics of the groundwater were of the calcium-chloride type. This water type is associated with a mixture of freshwater and saltwater. Specific conductance values less than $800 \mu \mathrm{S} / \mathrm{cm}$ were detected parallel to and east of the Río Coamo, which coincides with zones of elevated hydraulic conductivity in the study area delineated by Renken and others (2002) and areas of streamflow infiltration from the Río Coamo (Kuniansky and others, 2003). The specific conductance values in the area west of Rio Coamo ranged from 1,030 to $1,860 \mu \mathrm{S} / \mathrm{cm}$. The highest value $(1,860 \mu \mathrm{S} / \mathrm{cm})$ was detected in a well located near the outcrop of Ponce Limestone shown in figure 5. A comparison of the dissolved-solids estimates distribution in 2008 with dissolved-solids concentrations measured in 1986 (Gómez-Gómez, 1991 ) indicates the same general pattern of dissolvedsolids concentrations in the southern coastal plain, except its southeastern part where the maximum concentrations were $740 \mathrm{mg} / \mathrm{L}$ in 1986 and increased to $2,090 \mathrm{mg} / \mathrm{L}$ in 2008 .

\section{Pesticides}

Groundwater samples collected at 10 wells (table 4) in the study area were analyzed for 83 organic compounds used as pesticides (appendix 1). Analytical results indicated that 13 of these 83 organic compounds were detected in the samples. The detected organic compounds included 8 herbicides, 3 fungicides, and 2 insecticides. Pesticide concentrations include detections above and below the method reporting level (MRL) (fig. 9). The reported concentrations that are below the MRL, but are above the method detection level (MDL), are presented in table 4 as estimated values ("E" remark code).

The compounds with a frequency of detection above 50 percent were deethylatrazine (DEA), atrazine, simazine, and metolachlor (fig. 9). Atrazine, simazine, and metolachlor are herbicides, and deethylatrazine (DEA) is a metabolite and an environmental degradation product of atrazine and other triazine herbicides. DEA concentrations exceeded the parent compound (atrazine) concentration in 9 of the 10 sampled wells. The DEA to atrazine ratio (DAR) can be used as an indicator of atrazine residence time in soil during transport to groundwater (Thurman and Fallon, 1996; Iker and others, 2010). A high DAR value may indicate a long residence time for atrazine in the soil column, where it is exposed to conditions and processes that contribute to DEA formation (fig. 10).

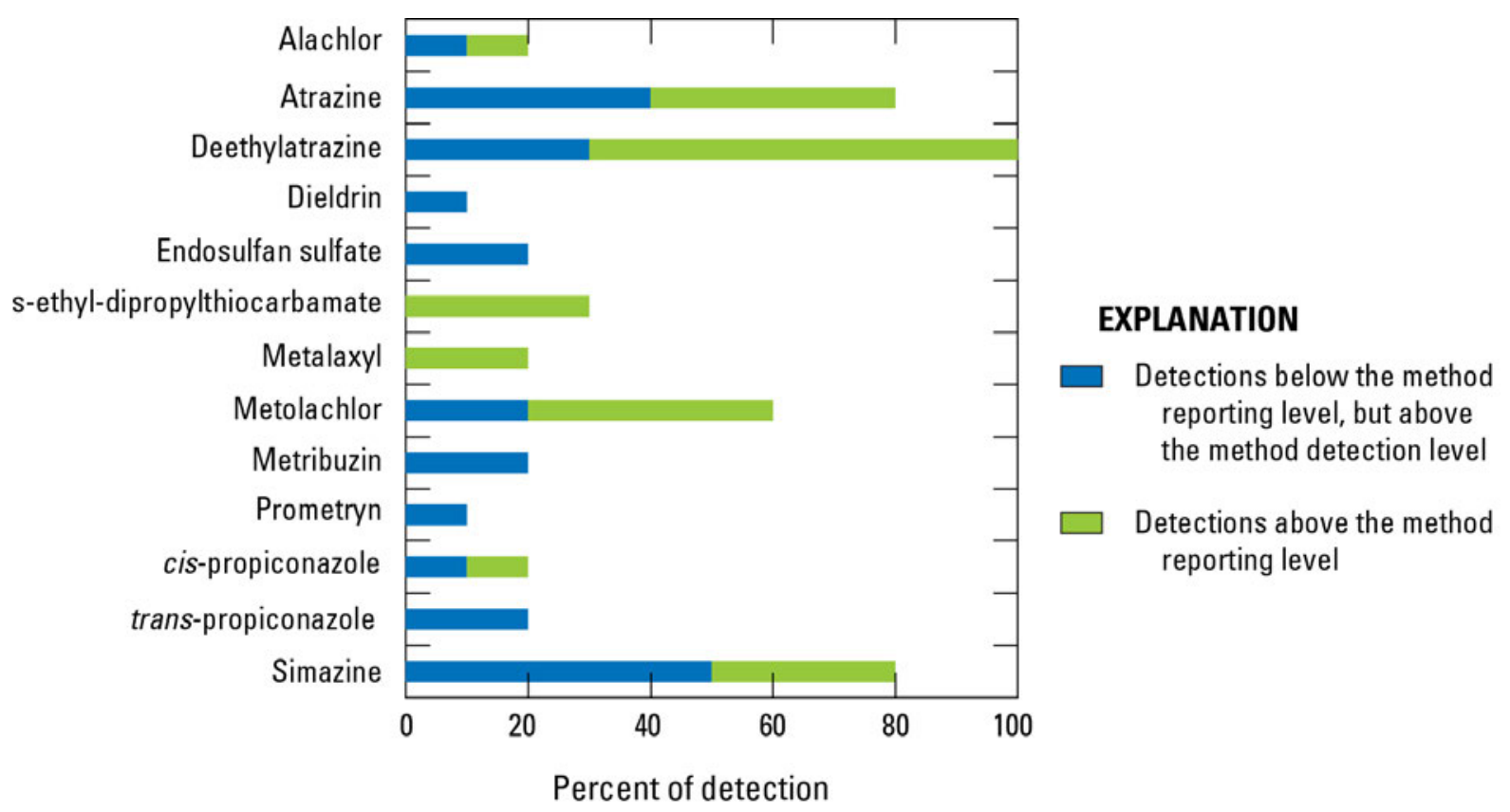

Figure 9. Frequency of detection of pesticide compounds in groundwater samples collected from selected wells in the Santa Isabel area, Puerto Rico, May 2008. 


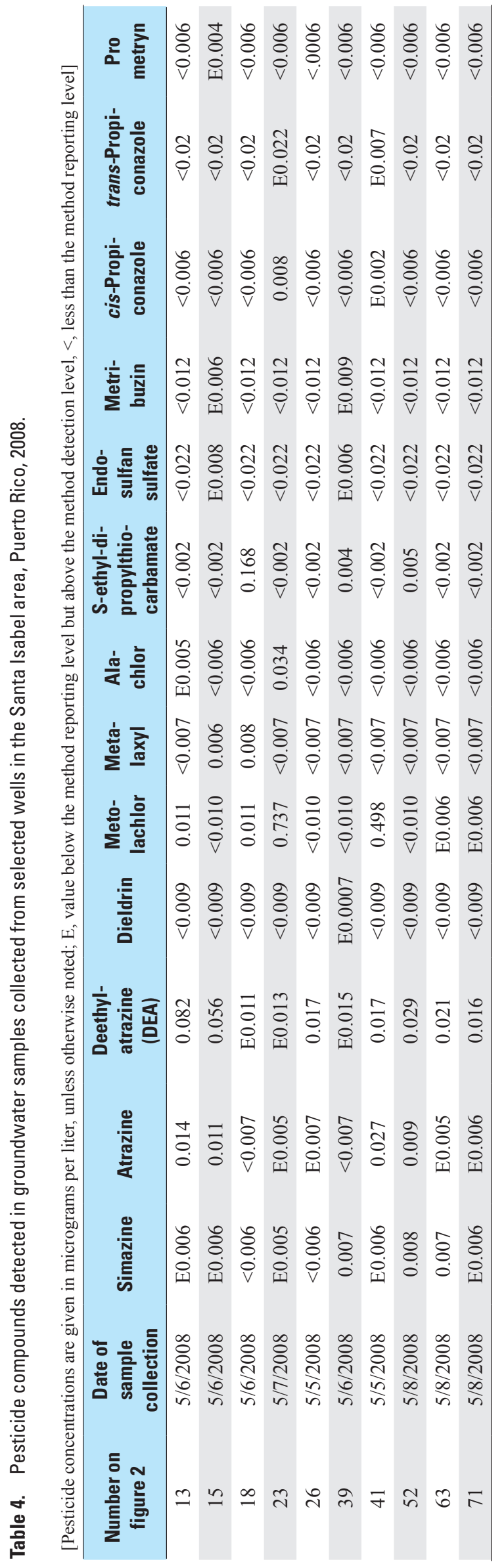




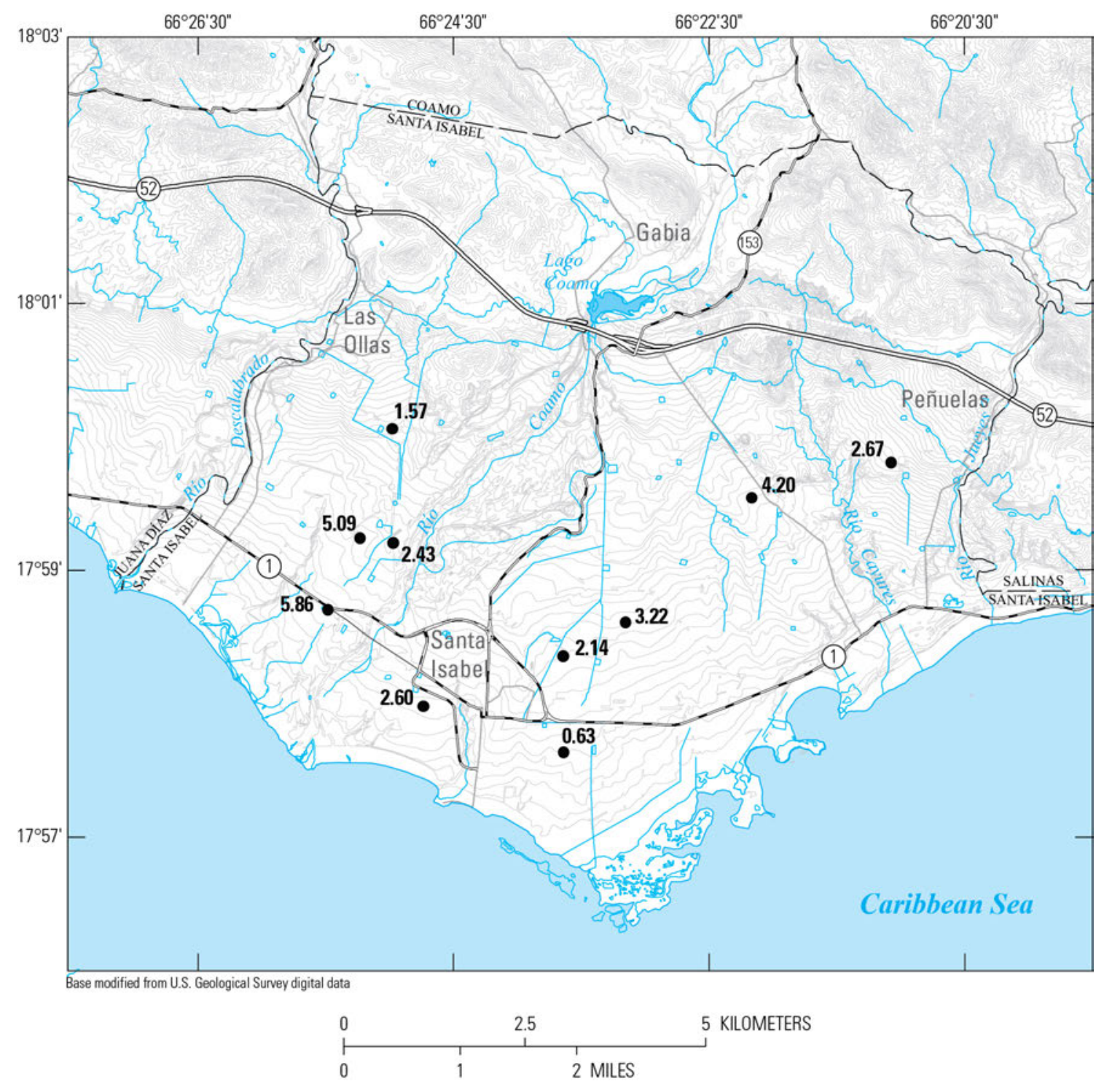

\section{EXPLANATION}

- 0.63 Well location and deethylatrazine-to-atrazine ratio (DAR)

Figure 10. Deethylatrazine-to-atrazine ratios (DAR) in groundwater samples collected from selected wells in the Santa Isabel area, Puerto Rico, May 2008. 
The sum of the concentrations of the pesticide compounds detected in the sampled wells ranged from 0.024 to 0.82 microgram per liter $(\mu \mathrm{g} / \mathrm{L})$ (fig. 11). The MCL for drinking water for atrazine and simazine are 3 and $4 \mu \mathrm{g} / \mathrm{L}$, respectively (U.S. Environmental Protection Agency, 2009).

The Groundwater Ubiquity Score (GUS) index (Gustafson, 1989) can be used to rank pesticides according to their potential to leach into groundwater. The GUS was calculated for 11 of the 13 detected compounds (table 5). The GUS is an index based on the graphical examination of a plot formed by two pesticide properties: half-life in soil $\left(\mathrm{t}_{1 / 2}\right)$ and partition coefficient between soil organic carbon and water (Koc). The GUS is determined using the following equation:

$$
\text { GUS }=\log _{10}\left(\mathrm{t}_{1 / 2}\right) \times\left[4-\log _{10}(\mathrm{Koc})\right] .
$$

Pesticides that have a GUS value higher than 2.8 are compounds classified as "leachers," with a high risk for contaminating groundwater. Pesticides with GUS values between 1.8 and 2.8 are "marginal compounds," and compounds with a GUS value lower than 1.8 are classified as "non-leachers." Atrazine, metolachlor, and simazine, which had a detection frequency above 50 percent during this study, are compounds classified as "leachers." Metalaxyl and metribuzin are also compounds classified a "leachers", but both compounds had a lower detection frequency during this study. Alachlor, prometryn, and propiconazole are classified as "marginal leachers." Dieldrin, endosulfan, and s-ethtyldipropyl-thiocarbamate (EPTC) are classified as "nonleachers."

According to interviews with farm managers, the most commonly used pesticides for crops in the study area during 2008 were endosulfan, atrazine, and metolachlor. Endosulfan was used for vegetables, tomatoes, and corn crops. Atrazine was used for vegetables, corn crops, and probably was applied to land in the past during sugarcane production. Metolachlor was used for vegetables, soy, and corn crops.

\section{Nitrate}

Analyses of groundwater samples collected during May 2008 and April 2009 indicated nitrate concentrations ranged from 1.3 to $23.6 \mathrm{mg} / \mathrm{L}$ nitratenitrogen $\left(\mathrm{NO}_{3}-\mathrm{N}\right)$ in wells located in the coastal plain, and from 5.5 to $15.2 \mathrm{mg} / \mathrm{L} \mathrm{NO}_{3}-\mathrm{N}$ in wells 73 and 74 located in the Gabia area (table 2 and fig. 12A). A comparison of nitrate concentrations determined during the study with those obtained during 1967 (National Water Information System) (fig. 12B) indicated that nitrate concentrations increased by a factor of about 7 within some areas of the aquifer in the coastal plain. In
$1967, \mathrm{NO}_{3}-\mathrm{N}$ concentrations within the greater part of the aquifer averaged $3.1 \mathrm{mg} / \mathrm{L}$, and ranged from 0.9 to $5.9 \mathrm{mg} / \mathrm{L} \mathrm{NO}_{3}-\mathrm{N}$ in a group of 20 samples

(U.S. Geological Survey, 2012).

Concentrations of $\mathrm{NO}_{3}-\mathrm{N}$ in surface water ranged from 0.19 to $1.98 \mathrm{mg} / \mathrm{L}$ (table 3 and fig $12 A$ ) during May 2008 and April 2009. No data for nitrate concentrations in surface water in 1967 were available for comparison. Measured nitrate concentrations were greater in Río Descalabrado than in Río Coamo.

The $\mathrm{NO}_{3}-\mathrm{N}$ concentration pattern shown in figure $12 \mathrm{~A}$ indicates that the movement of groundwater with low (less than $5 \mathrm{mg} / \mathrm{L}$ ) concentrations is associated with surface-water infiltration from Río Coamo toward the center of the study area. Two areas having elevated $\mathrm{NO}_{3}-\mathrm{N}$ concentrations greater than $10 \mathrm{mg} / \mathrm{L}$ (fig. 12A) were detected during the study, one in the south-central part of the study area and the other west of Río Coamo. The areas of elevated $\mathrm{NO}_{3}-\mathrm{N}$ concentrations partially overlap the two cones of depression (fig. 6) created by groundwater pumping centers. $\mathrm{NO}_{3}-\mathrm{N}$ concentrations above the MCL of $10 \mathrm{mg} / \mathrm{L}$ for drinking water (U.S. Environmental Protection Agency, 2009) were detected in 15 wells in the coastal plain and 1 well in the foothills. All of the wells exceeding the nitrate MCL were used for agriculture.

\section{Sources of Nitrate}

Nitrate is one of the primary forms of dissolved nitrogen in ambient water and is produced by the rapid oxidation of its reduced or organic forms. Nitrate is generally the dominant form in waters containing dissolved oxygen, is highly soluble, and is readily transported in groundwater. Nitrate in groundwater can originate from organic nitrogen complexes, such as animal manure or septic waste discharges, that are converted to (1) ammonia nitrogen through the processes of ammonification (the decomposition of organic matter into ammonium ions), and (2) nitrate by nitrification (the oxidation of ammonium to nitrate). Nitrification is an aerobic process that can cause an accumulation of nitrate in groundwater (Chapelle, 1993). Denitrification is the process by which nitrate is reduced to nitrogen gas and is the prevalent process by which nitrate is lost from groundwater.

The intensive use of fertilizers in the cultivation of corn, vegetables, tomatoes, bananas, and other crops suggests that farmland cultivation has the greatest potential for increasing nitrate concentrations in the aquifer in the study area. The other potential sources of nitrate in the study area are animal farms, leakage from sewer mains, and leakage from septic tanks in unsewered communities. 


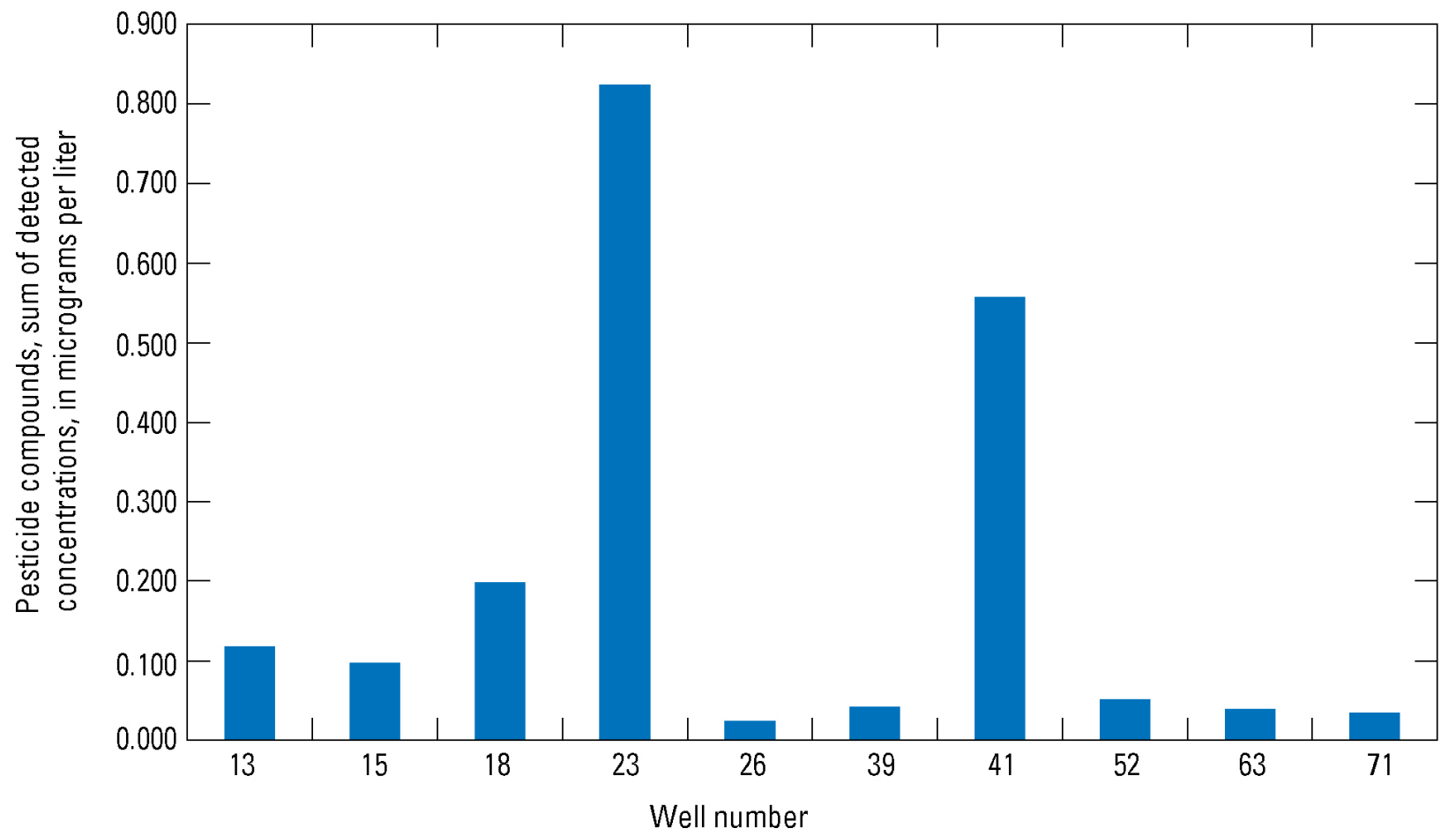

Figure 11. Sum of detected concentrations of pesticide compounds in groundwater samples collected from selected wells in the Santa Isabel area, Puerto Rico, May 2008.

Table 5. Groundwater ubiquity score (GUS) index (Gustafson, 1989) for pesticide compounds detected in groundwater samples collected from selected wells in the Santa Isabel area, Puerto Rico, 2008.

[Koc, partition coefficient between soil organic water and water; GUS $>2.3$, leacher; GUS 1.8-2.8, marginal leacher; GUS $<1.8$, non-leacher]

\begin{tabular}{lrrrc}
\hline \multicolumn{1}{c}{ Compound } & Half life in soil' (days) & Koc $^{\mathbf{1}}$ & $\begin{array}{c}\text { Groundwater Ubiquity } \\
\text { Score (GUS) Index }\end{array}$ & Leaching potential \\
\hline Alachor & 15 & 170 & 2.08 & Marginal leacher \\
Atrazine & 60 & 100 & 3.56 & Leacher \\
\hline Dieldrin & 1,000 & 12,000 & -0.24 & Non-leacher \\
Endosulfan & 50 & 12,400 & -0.16 & Non-leacher \\
EPTC & 6 & 200 & 1.32 & Non-leacher \\
Metalaxil & 70 & 50 & 4.25 & Leacher \\
Metolachor & 90 & 200 & 3.32 & Leacher \\
Metribuzin & 40 & 60 & 3.56 & Leacher \\
Prometryn & 60 & 400 & 2.49 & Marginal leacher \\
Propiconazole & 110 & 650 & 2.42 & Marginal leacher \\
Simazine & 60 & 130 & 3.35 & Leacher \\
\hline
\end{tabular}

\footnotetext{
${ }^{1}$ Oregon State University Pesticides Properties Database
} 


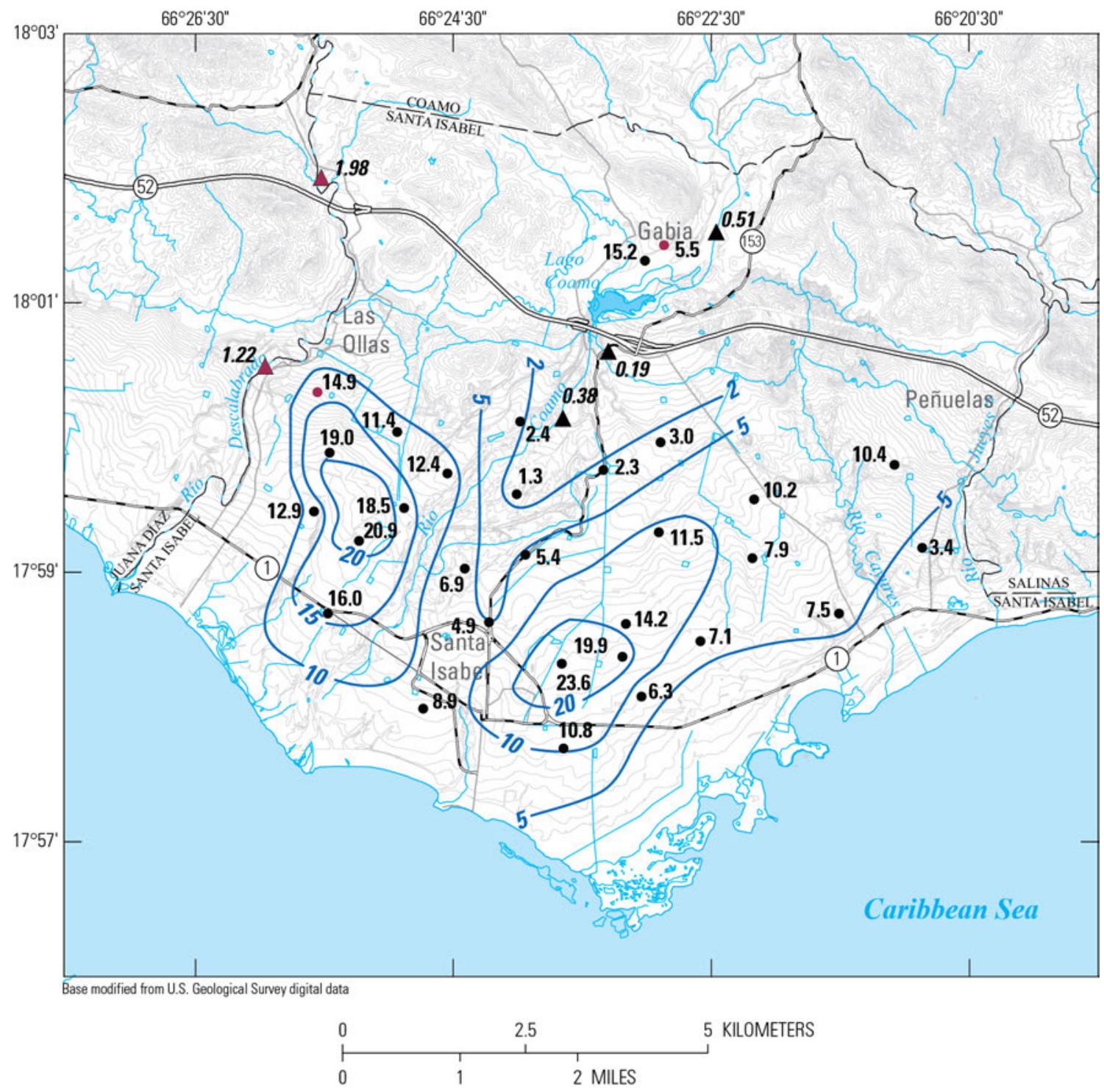

EXPLANATION

$-5-$ Line of equal nitrate concentration. Contour interval variable

10.8 Groundwater quality data control point-Number is nitrate concentration as nitrogen, in milligrams per liter. Control point in red color indicates data collected on April 2009.

$\Delta$ 1.2 Surface-water quality data control point-Number is nitrate concentration as nitrogen, in milligrams per liter. Control point in red color indicates data collected on April 2009.

Figure 12A. Nitrate concentrations in groundwater and surface water in the Santa Isabel area, Puerto Rico, during $(A)$ May 2008 to April 2009 and $(B)$ February to October, 1967. 


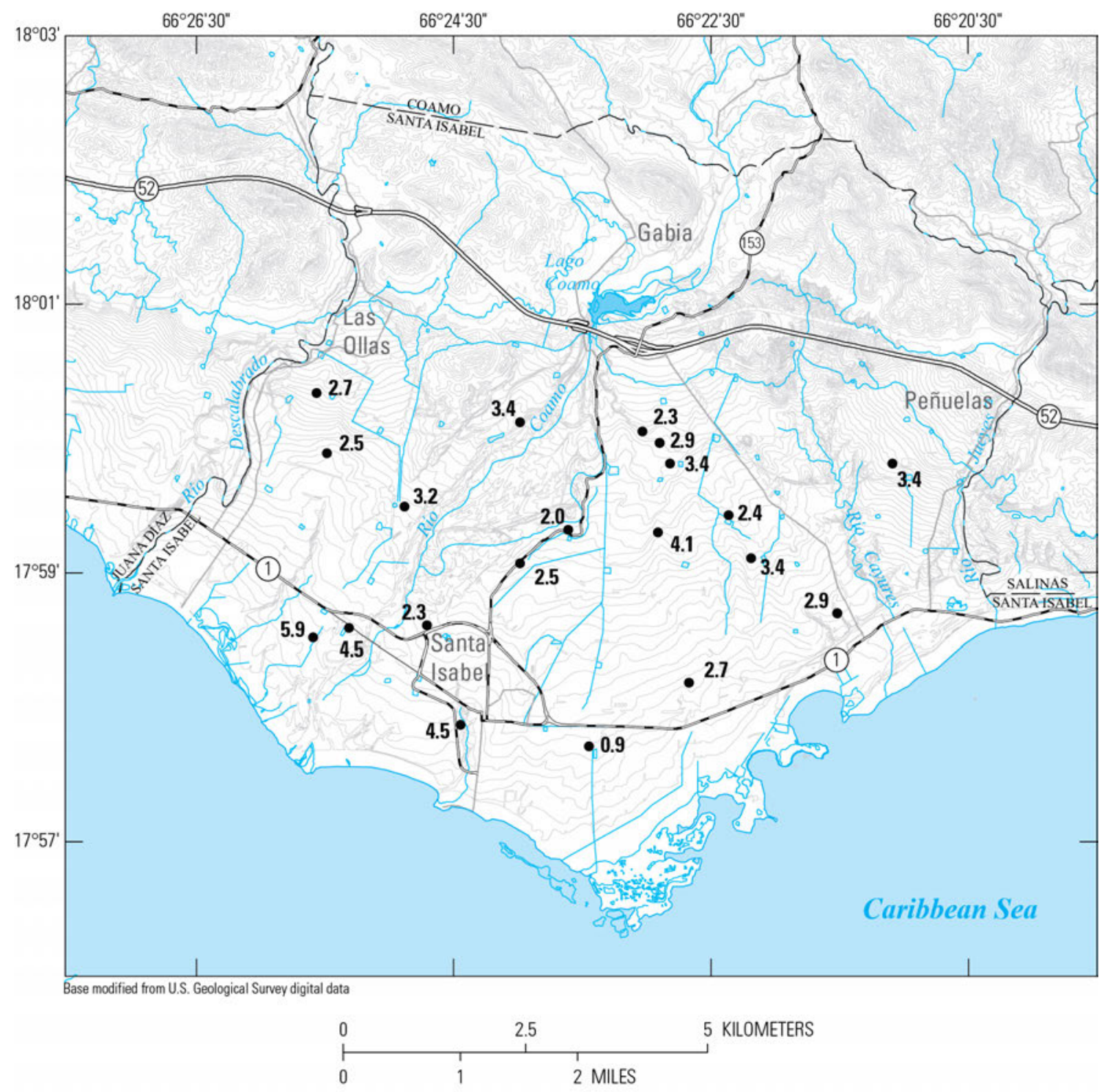

\section{EXPLANATION}

- 0.9 Well location and nitrate as nitrogen concentration

Figure 12B. Nitrate concentrations in groundwater and surface water in the Santa Isabel area, Puerto Rico, during $(A)$ May 2008 to April 2009 and $(B)$ February to October, 1967. 
Fertilizers containing nitrogen used in the croplands within the study area include urea, $\mathrm{CO}\left(\mathrm{NH}_{2}\right)_{2}$, ammonium sulfate, $\left(\mathrm{NH}_{4}\right)_{2} \mathrm{SO}_{4}$, and ammonium nitrate, $\mathrm{NH}_{4} \mathrm{NO}_{3}$. Urea is mostly used in the study area for banana, plantain, corn, vegetable, mango, and papaya crops.

Septic-tank leachate is a probable source of nitrate in groundwater in shallow aquifers. Septic tanks remove most settleable solids and floatable material and function as an anaerobic bioreactor. Septic tank densities in a community, however, may exceed the capacity of even suitable soils to assimilate wastewater flows and retain and transform their contaminants. In such cases, septic tanks represent a source of nitrate to the aquifer.

\section{Nitrogen and Oxygen Isotopic Characterization of Nitrate Sources}

Groundwater samples collected in the study area were analyzed for delta nitrogen-15 $\left(\delta^{15} \mathrm{~N}-\mathrm{NO}_{3}\right)$ and delta oxygen-18 $\left(\delta^{18} \mathrm{O}-\mathrm{NO}_{3}\right)$ in nitrate (table 2$)$. The combined use of $\delta^{15} \mathrm{~N}-\mathrm{NO}_{3}$ and $\delta^{18} \mathrm{O}-\mathrm{NO}_{3}$ provides a tool for distinguishing between the following major nitrate sources: atmospherically deposited nitrate, nitrate in synthetic fertilizers, nitrate derived from soil nitrification, and nitrate in manure and sewage (Mayer, 2005). Typical $\delta^{15} \mathrm{~N}-\mathrm{NO}_{3}$ and $\delta^{18} \mathrm{O}-\mathrm{NO}_{3}$ values in groundwater associated with various sources are presented in figure 13 (Clark and Fritz, 1997; Kendall, 1998; and Mayer, 2005).

Groundwater samples collected during 2008 and 2009 from wells within the coastal plain had $\mathrm{NO}_{3}-\mathrm{N}$ concentrations between 1.3 and $23.6 \mathrm{mg} / \mathrm{L}$ (table 2) and $\delta^{15} \mathrm{~N}-\mathrm{NO}_{3}$ values from +4.9 to $+14.6 \%$ (fig. 14). Groundwater samples collected from wells within the cultivated farmland had $\delta^{15} \mathrm{~N}-\mathrm{NO}_{3}$ values from +4.9 to $+11.5 \%$ and $\delta^{18} \mathrm{O}-\mathrm{NO}_{3}$ values from +3.5 to +8.9 . Samples from wells in the eastern and west-central parts of the intensively cultivated sections of the study area had $\delta^{15} \mathrm{~N}_{-} \mathrm{NO}_{3}$ values from $+5.3 \%$ to $+7.6 \%$ and $\delta^{18} \mathrm{O}-\mathrm{NO}_{3}$ values from $+3.8 \%$ to $+7.5 \%$, which are associated with soil nitrogen according to Clark and Fritz (1997) and Mayer (2005) (figs. 13 and 14). Considering the intensive use of synthetic fertilizers and the high nitrate concentrations detected in the areas located east and west of Río Coamo, it is likely that soil nitrate produced by ammonia volatilization of nitrogen fertilizer, which is isotopically more positive, percolates to the groundwater system.

Soil nitrogen exists in inorganic and organic forms, with organic forms being predominant. Biological processes in the soil convert organic nitrogen present in plant residues and other organic matter to inorganic forms. Farms in the eastern and central parts of the study area are intensively cultivated for tomato, corn, and vegetables. Nitrate loss from mineralized crop residues may also increase nitrate concentrations in groundwater in the study area.

Values of $\delta^{15} \mathrm{~N}^{-\mathrm{NO}_{3}}$ and $\delta^{18} \mathrm{O}-\mathrm{NO}_{3}$ in the northcentral part of the study area and near the margins of the intensively cultivated farmland (fig. 14, table 2) exceed $+9 \%$ and $+6 \%$, respectively. These values coincide with the low $\mathrm{NO}_{3}-\mathrm{N}$ and low dissolved-solids concentrations discussed previously, and with areas of streamflow infiltration from Río Coamo into the aquifer (Kuniansky and others, 2003). Two surface-water samples collected from Río Coamo had $\mathrm{NO}_{3}-\mathrm{N}$ concentrations of 0.51 and $0.38 \mathrm{mg} / \mathrm{L}$ and $\delta^{15} \mathrm{~N}-\mathrm{NO}_{3}$ values of +17.6 and $+14.0 \%$. The relation between $\delta^{15} \mathrm{~N}-\mathrm{NO}_{3}$ and $\delta^{18} \mathrm{O}-\mathrm{NO}_{3}$ (fig. 13) suggests that nitrate concentrations in the north-central part of the study area (fig. 2, wells $31,33,35,47$, and 49), southeast of the urban center of Santa Isabel (fig. 2, well 41) and eastward near the Peñuelas community (fig. 2, wells 69 and 71) are associated with organic waste that is possibly related to leakage from septic systems or sewer mains.

Biogeochemical reactions such as denitrification can alter the isotopic composition of nitrogen. Denitrification causes the $\delta^{15} \mathrm{~N}$ of the residual nitrate to increase as nitrate concentration decreases. The $\delta^{18} \mathrm{O}-\mathrm{NO}_{3}$ value is useful in determining whether denitrification is occurring in the system. The ratio of enrichment of oxygen relative to nitrogen of $\delta^{18} \mathrm{O}-\mathrm{NO}_{3}$ and $\delta^{15} \mathrm{~N}-\mathrm{NO}_{3}$ is approximately 1:2 when denitrification is occurring (Kendall, 1998). General groundwater flow in the study area is southward; therefore, the increasing nitrate concentrations in that direction cannot be explained by denitrification because this process along the flowpath would result in decreasing nitrate concentrations and increases in $\delta^{15} \mathrm{~N}-\mathrm{NO}_{3}$ and $\delta^{18} \mathrm{O}-\mathrm{NO}_{3}$ values. A mixing process therefore seems more probable than denitrification in the north-central part of the study area.

The mixture of two end-members that have different isotope ratios and different concentrations of a given element form hyperbolas when the isotopes ratios are plotted against concentration (Kendall, 1998). Mixing hyperbolas can be transformed into straight lines by plotting isotopes ratios against the inverse of the concentration. The relation between $\delta^{15} \mathrm{~N}^{-\mathrm{NO}_{3}}$ and the inverse of $\mathrm{NO}_{3}$ concentration in samples collected from wells in the central part of the study area (fig. 15) indicates a mixing of surface water from Río Coamo (low nitrate concentration and high $\delta^{15} \mathrm{~N}-\mathrm{NO}_{3}$ ), with groundwater having a greater nitrate concentration and lower $\delta^{15} \mathrm{~N}-\mathrm{NO}_{3}$. To verify if the data fit a fractionation process instead of a mixing process, the data were also plotted as $\delta^{15} \mathrm{~N}-\mathrm{NO}_{3}$ against the natural logarithm of $\mathrm{NO}_{3}-\mathrm{N}$ concentration (fig. 16). The denitrification process yields an exponential relation that will produce a straight line when delta ${ }^{15} \mathrm{~N}-\mathrm{NO}_{3}$ is plotted against the 


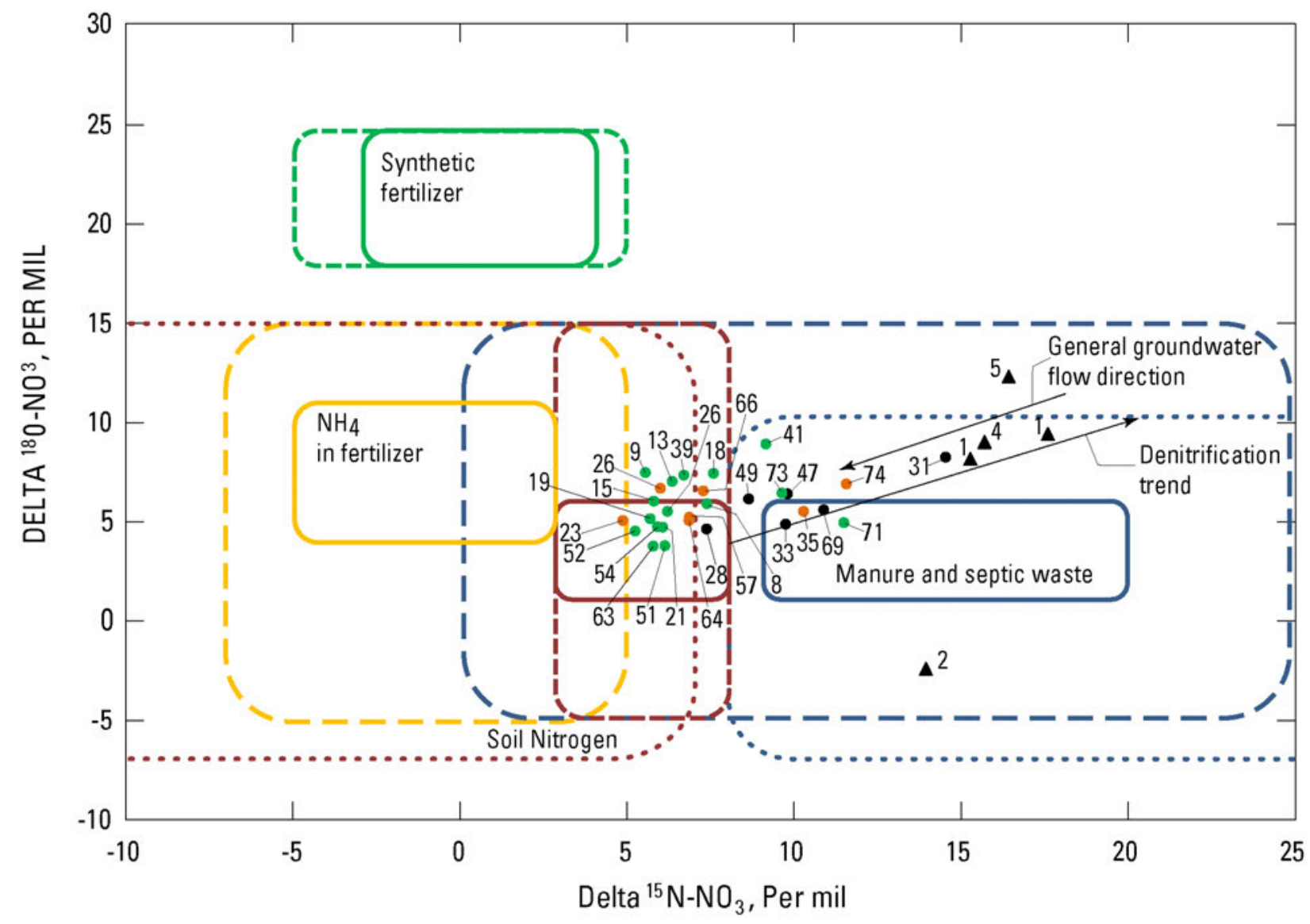

EXPLANATION

Range of the relation of delta nitrogen-15 $\left({ }^{15} \mathrm{~N}\right)$ and delta oxygen-18 $\left({ }^{18} \mathrm{O}\right)$ of nitrate associated to:

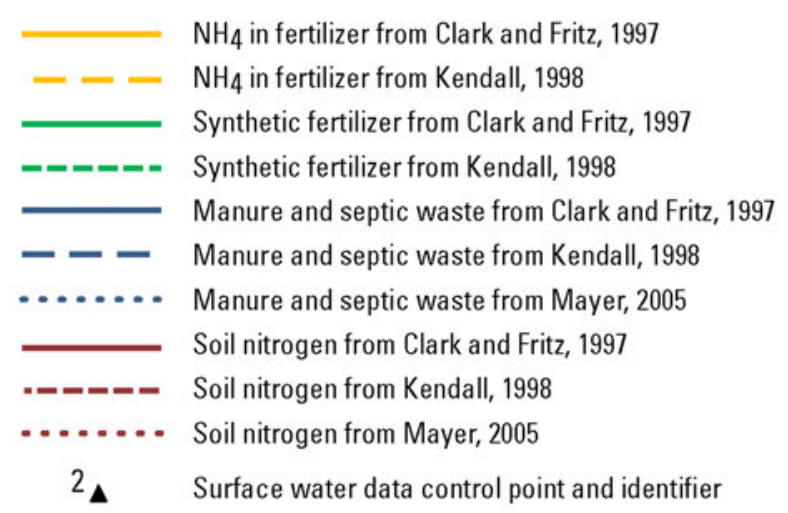

Groundwater data control point and identifier
28. $\mathrm{NO}_{3}-\mathrm{N}$ concentration $<5$ milligrams per liter
23. $\mathrm{NO}_{3}-\mathrm{N}$ concentration $>5<10$ milligrams per liter
63. $\mathrm{NO}_{3}-\mathrm{N}$ concentration $>10$ milligrams per liter

Figure 13. Relation of delta nitrogen-15 $\left({ }^{15} \mathrm{~N}\right)$ and delta oxygen-18 $\left({ }^{18} \mathrm{O}\right)$ of nitrate in groundwater and surface water in the Santa Isabel area, Puerto Rico, May 2008-April 2009. 


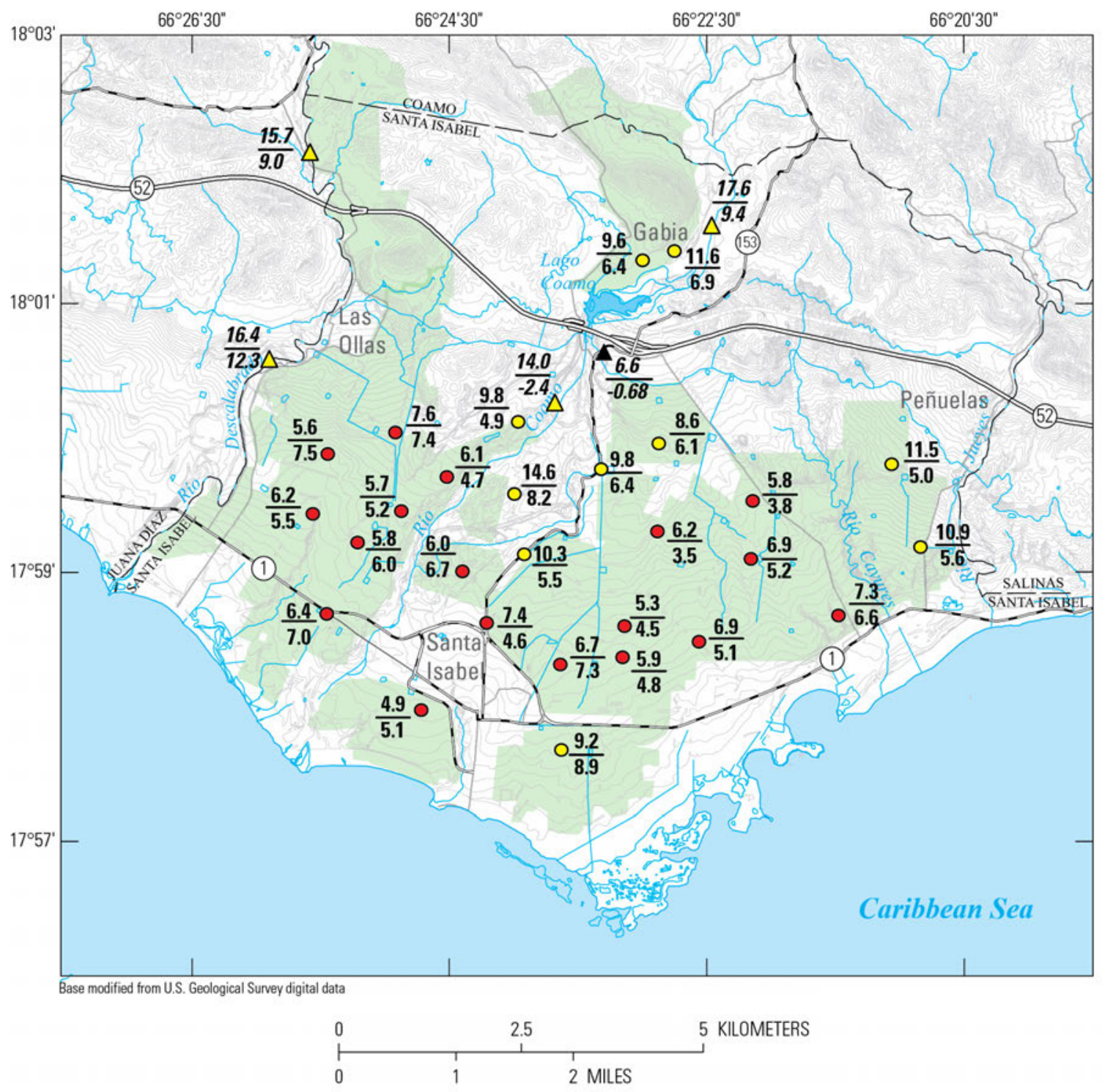

EXPLANATION

Agricultural land use

Groundwater quality data control point - number on top is delta nitrogen-15 of nitrate in per mil $(\% 0)$ and bottom number is delta oxygen-18 of nitrate in $\%$. Yellow color indicates delta nitrogen-15 greater than $+8 \%$ and oxygen-18 greater than $+1 \%$ and less than $+10 \%$

4.9 Groundwater quality data control point-number on top is delta nitrogen-15 of nitrate in per mil $(\% 0)$ 0.1 and bottom number is delta oxygen-18 of nitrate in $\%$. Red color indicates delta nitrogen-15 greater than $+3 \%$ and less than $+8 \%$ and oxygen-18 greater than $+1 \%$ and less than $+10 \%$

16.4 Surface water quality data control point-number on top is delta nitrogen-15 of nitrate in per mil $(\% 0)$ $\Delta^{\overline{12.3}}$ and bottom number is delta oxygen-18 of nitrate in $\%$

Figure 14. Delta nitrogen-15 $\left({ }^{15} \mathrm{~N}\right)$ and delta oxygen-18 $\left({ }^{18} \mathrm{O}\right)$ of nitrate in groundwater and surface water in the Santa Isabel area, Puerto Rico, May 2008- April 2009. 


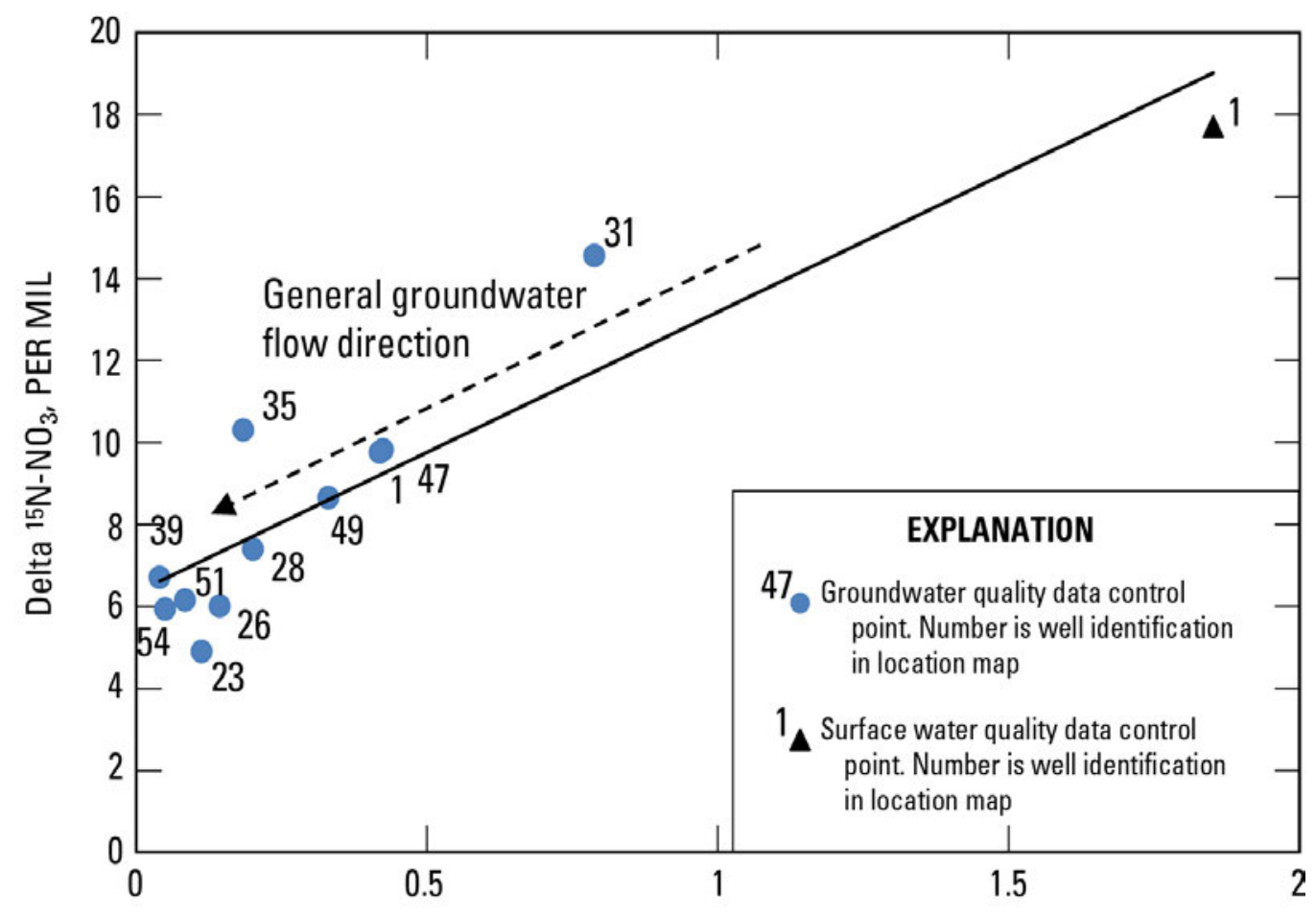

Inverse of nitrate as nitrogen concentration, in milligrams per liter

Figure 15. Relation of the inverse of nitrate concentration and delta nitrogen- $15\left({ }^{15} \mathrm{~N}\right)$ of nitrate in groundwater in the central section of the study area, Santa Isabel area, Puerto Rico, May 2008April 2009.

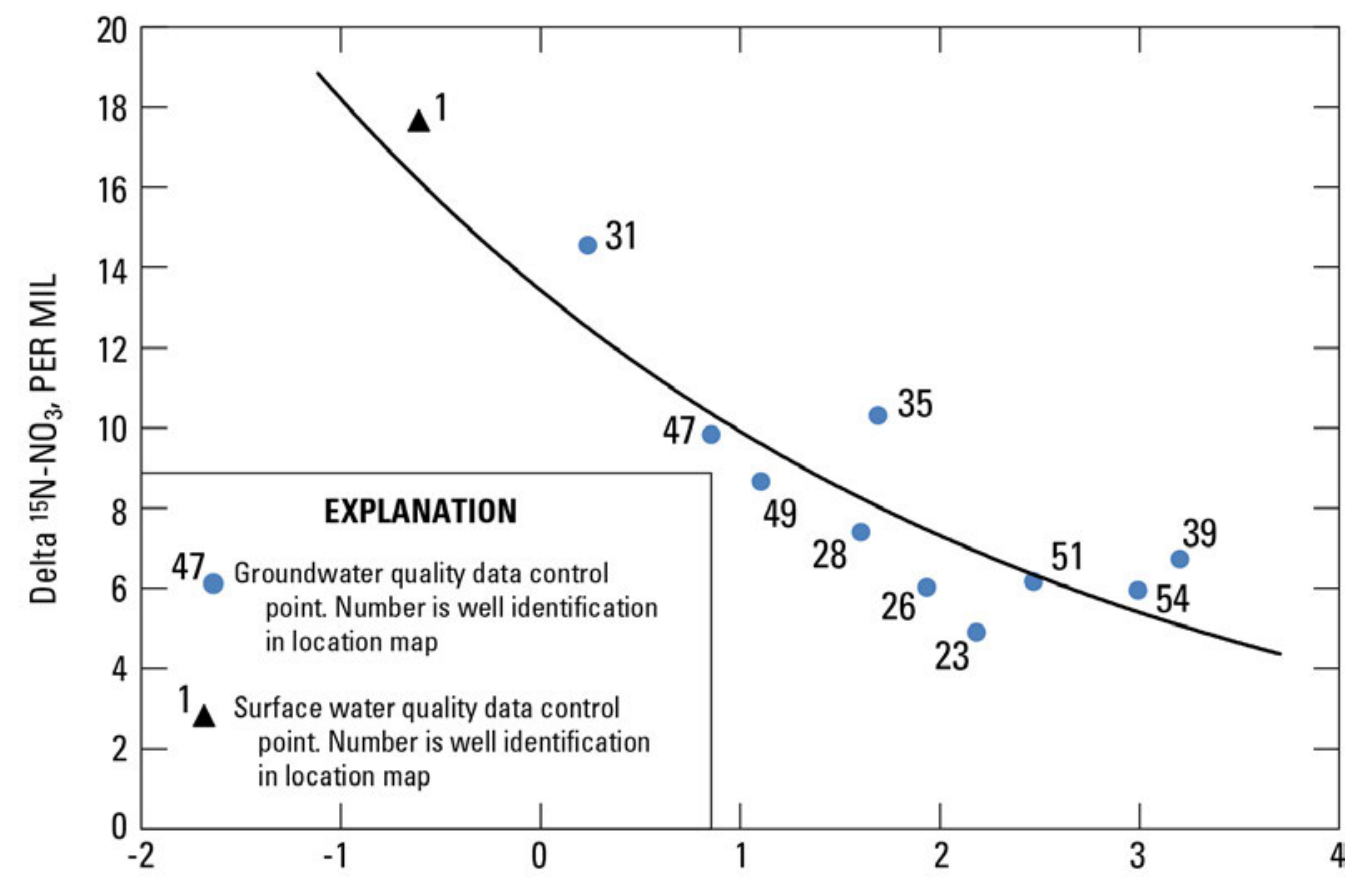

Natural logarithm of nitrate as nitrogen concentration, in milligrams per liter

Figure 16. Relation of the natural logarithm of nitrate concentration and delta nitrogen-15 $\left({ }^{15} \mathrm{~N}\right)$ of nitrate in groundwater in the central section of the study area, Santa Isabel area, Puerto Rico, May 2008- April 2009. 
Table 6. Potential nitrogen load estimates from fertilizers applied to crops and other sources in the study area, Santa Isabel, Puerto Rico, 2008.

[kg N/ha-yr, kilogram of nitrogen per hectare per year; N, nitrogen; ha, hectare; kg N/yr, kilogram of nitrogen per year; na, not applicable]

\begin{tabular}{|c|c|c|c|c|c|}
\hline Crop or source & $\begin{array}{l}\text { Fertilizer application } \\
\text { rate, as kg N/ha-yr }\end{array}$ & $\begin{array}{l}\text { Crop nitrogen up- } \\
\text { take, as kg N/ha-yr }\end{array}$ & $\begin{array}{l}\text { Potential residual } \\
\mathrm{N} \text {, as kg N/ha-yr }\end{array}$ & Cultivated area, ha & $\begin{array}{l}\text { Total residual } \\
\mathrm{N} \text {, in } \mathrm{kg} \mathrm{N} / \mathrm{yr}\end{array}$ \\
\hline Bananas & $154-340$ & $112^{\mathrm{a}}$ & $42-228$ & 192 & $8,064-43,778$ \\
\hline Mango & 78 & $42^{\mathrm{a}}$ & 36 & 379 & 13,644 \\
\hline Soybeans & 225 & $219^{b}$ & 6 & 122 & 732 \\
\hline $\begin{array}{l}\text { Vegetables and } \\
\text { papaya }\end{array}$ & $74-156$ & $18-64^{a}$ & 88 & 796 & 70,048 \\
\hline $\begin{array}{l}\text { Un-sewered } \\
\text { communities }\end{array}$ & $\mathrm{n} / \mathrm{a}$ & $\mathrm{n} / \mathrm{a}$ & $\mathrm{n} / \mathrm{a}$ & $\mathrm{n} / \mathrm{a}$ & 9,400 \\
\hline
\end{tabular}

${ }^{a}$ Natural Resources Conservation Service, 2001

${ }^{\mathrm{b}}$ Salvagiotti and others, 2008

natural logarithm of $\mathrm{NO}_{3}-\mathrm{N}$ concentration (Kendall, 1998).

The $\delta^{15} \mathrm{~N}-\mathrm{NO}_{3}$ and $\delta^{18} \mathrm{O}-\mathrm{NO}_{3}$ signatures for the groundwater samples (wells 28, 31, 35, 47, and 49) and surface-water samples from Rio Coamo (sites 1 and 4) collected in the north-central part of the of the study area plot according to the general groundwater flow direction, but inverse to the theoretical denitrification trend (fig. 13), which also suggests that a surface-water and groundwater mixing process is occurring in the area.

The relation between $\delta^{15} \mathrm{~N}-\mathrm{NO}_{3}$ and $\delta^{18} \mathrm{O}-\mathrm{NO}_{3}$ in the study area (fig. 13) indicates that the groundwater samples collected from wells 73 and 74 within the Gabia area had values in the range associated with organicwaste nitrate sources.

The four surface-water samples collected from Río Coamo and Río Descalabrado showed a relation between $\delta^{15} \mathrm{~N}-\mathrm{NO}_{3}$ and $\delta^{18} \mathrm{O}-\mathrm{NO}_{3}$ in the range associated to manure and septic waste nitrate sources (fig. 13). Water samples collected at stations Río Coamo near Paso Seco (site 2) and Canal de Juana Díaz at Paso Seco

(site 3) had distinctive $\delta^{18} \mathrm{O}-\mathrm{NO}_{3}$ signatures and ammonia concentrations (table 3 ). Site 2 is located downstream from Lago Coamo, and site 3 is located in an irrigation canal that conveys surface water from Lago Guayabal (fig. 1). The distinctive ammonia concentrations may be caused by the decay of organic matter present in these reservoirs, and the distinctive $\delta^{18} \mathrm{O}-\mathrm{NO}_{3}$ signatures may be associated with the nitrification of ammonia.

\section{Potential Nitrate Load to the Aquifer}

Fertilizer applied to cropland within the study area represents a major source of nitrate to the aquifer. The potential nitrogen load from agricultural land under cultivation in the study area is variable and depends on many factors, including the type of crop under cultivation and the fertilizer management practices in use (table 6). The fertilizer application rates were estimated on the basis of data obtained from interviews with farmers in the study area. Only a fraction of the nitrogen contained in fertilizer used in cropland remains available to migrate to the subsurface, because most is either incorporated into the vegetation or mineralized within the soil.

The potential amounts of nitrogen from fertilizer used on crops that can be leached to the aquifer were estimated by subtracting the nitrogen uptake of the different crops in the study area from the amount of nitrogen contained in fertilizers applied to the crops (table 6). As an example, the reported nitrogen application for corn crops is estimated to range from approximately 225 to 240 kilograms N per hectare-year (kg-N/ha-yr). The uptake of nitrogen is estimated to be approximately $174 \mathrm{~kg}-\mathrm{N} / \mathrm{ha}-\mathrm{yr}$ (Natural Resources Conservation Service, 2001) of the applied nitrogen. The amount of nitrogen available for volatilization, mineralization, and potential migration to the aquifer ranges from 51 to $66 \mathrm{~kg}-\mathrm{N} / \mathrm{ha}-\mathrm{yr}$. The residual amount of nitrogen that has the potential to affect the aquifer is estimated to range from about 15,200 to 19,700 kilograms $\mathrm{N}$ per year $(\mathrm{kg}-\mathrm{N} / \mathrm{yr})$ for the 298 ha of corn cropland reported in 2008. The estimates obtained for 
the other crops, using the same method, are presented in table 6.

Poultry farms in the Gabia area represent the other potential agricultural source of nitrate in the study area and ceased operation in 2007. Interviewed farm owners stated that partial removal of the poultry litter was conducted approximately every 3 months, and that the removed litter was transported out of the Gabia area and processed for use as cattle food. Because the poultry litter was not disposed, spread, or integrated into the soil of the farms in the Gabia area, it is assumed that the nitrogen load from this source is negligible.

The potential nitrate load to the aquifer from septic systems in the Peñuelas and Las Ollas areas, two communities without sanitary sewer systems, was estimated by multiplying the population of each community in 2000 by the per-capita total nitrogen excreted by humans, which averages 17 grams per day (g/d) (Kaplan, 1987). Based on 381 housing units and an average of 3 persons per household within the Peñuelas community (U.S. Census Bureau, 2002), the estimated nitrogen load for the community is 7,090 kg-N/yr. An approximate $\mathrm{NO}_{3}-\mathrm{N}$ load of $3,545 \mathrm{~kg}-\mathrm{N} / \mathrm{yr}$ is estimated if it is assumed that only 50 percent of the excreted nitrogenous compounds will result in nitrate. The estimated total area contained within the alluvial fan in the Peñuelas area with unsewered housing is $35 \mathrm{ha}$; therefore, a potential $\mathrm{NO}_{3}-\mathrm{N}$ load of about $101 \mathrm{~kg}-\mathrm{N} / \mathrm{ha}-\mathrm{yr}$ is estimated for the Peñuelas community.

The potential nitrate load to the aquifer from septic tanks of the Las Ollas community was estimated based on 651 housing units and 3 persons per household within the community (U.S. Census, 2000), the estimated nitrogen load for the Las Ollas community is $12,120 \mathrm{~kg}-\mathrm{N} / \mathrm{yr}$. Assuming that only 50 percent of the excreted nitrogenous compounds will result in nitrate, an approximate $\mathrm{NO}_{3}-\mathrm{N}$ load of $6,060 \mathrm{~kg}-\mathrm{N} / \mathrm{yr}$ is estimated. The estimated total area of Las Ollas with unsewered housing is $31 \mathrm{ha}$; therefore, a potential $\mathrm{NO}_{3}-\mathrm{N}$ load of about $195 \mathrm{~kg}-\mathrm{N} / \mathrm{ha}-\mathrm{yr}$ is estimated for the Las Ollas community.

Another source of nitrogen related to the agricultural activities in the study area is the recirculation of groundwater (for irrigation) that has an elevated $\mathrm{NO}_{3}-\mathrm{N}$ concentration. For the purpose of discussion in this report the western sector of the study area is limited to the west by the Río Descalabrado and to the east by the Río Coamo. The central sector is limited to the west by the Río Coamo and to the east by the Río Cayures. In the central sector of the study area, groundwater $\mathrm{NO}_{3}-\mathrm{N}$ concentrations ranged from 1.3 to $23.6 \mathrm{mg} / \mathrm{L}$ (fig. $12 \mathrm{~A}$ ). The estimated nitrogen load from groundwater in this area was calculated using the sum of the load from groundwater for each well, which is determined by multiplying the $\mathrm{NO}_{3}-\mathrm{N}$ concentration for the sample collected in kilogram per cubic meter and the total annual groundwater withdrawal from the well in cubic meters per year (table 7). For wells used for irrigation, but not sampled during the study, the $\mathrm{NO}_{3}-\mathrm{N}$ concentration was estimated using figure $12 \mathrm{~A}$. For example, for well 39 the $\mathrm{NO}_{3}-\mathrm{N}$ concentration of $23.6 \mathrm{mg} / \mathrm{L}$ (equivalent to 0.0236 kilogram per cubic meter $\left.\left(\mathrm{kg} / \mathrm{m}^{3}\right)\right)$ was multiplied by the estimated groundwater withdrawal for that well during 2008 of $193,435 \mathrm{~m}^{3} / \mathrm{yr}$, which resulted in an estimated load of $4,565 \mathrm{~kg}-\mathrm{N} / \mathrm{yr}$ (table 7). The load of $\mathrm{NO}_{3}-\mathrm{N}$ from the irrigation water to the farms in the central sector of the study area was estimated as approximately $60,900 \mathrm{~kg}-\mathrm{N} / \mathrm{yr}$. In the western sector of the study area, groundwater $\mathrm{NO}_{3}-\mathrm{N}$ concentrations ranged from 5.0 to $20.9 \mathrm{mg} / \mathrm{L}$ (fig. $12 A$ ). The load of $\mathrm{NO}_{3}-\mathrm{N}$ from the irrigation water to the farms in the western sector was estimated as approximately $56,000 \mathrm{~kg}-\mathrm{N} / \mathrm{yr}$. The net effect of the nitrogen load from the recirculation of groundwater is assumed to be zero, however, because the load is removed from the aquifer and then added back.

The principal potential nitrogen load from sources in the study area expressed on a unit area basis and by total land-use area is summarized in table 6. Principal nitrogen sources were fertilizer used at vegetable and papaya farms $(70,048 \mathrm{~kg}-\mathrm{N} / \mathrm{yr})$, corn farms $(15,198$ to $19,668 \mathrm{~kg}-\mathrm{N} / \mathrm{yr})$, banana farms $(8,064$ to $43,778 \mathrm{~kg}-\mathrm{N} / \mathrm{yr})$, and mango farms $(13,644 \mathrm{~kg}-\mathrm{N} / \mathrm{yr})$.

Generalized estimates of the expected nitrate concentration in groundwater contained within the western and central sections of the study area were obtained by dividing the potential nitrate load for each area (table 8 ) by the estimated rainfall recharge rate of 0.10 meter per year $(\mathrm{m} / \mathrm{yr})$ and surface area of about 16.8 and 30.8 square kilometers $\left(\mathrm{km}^{2}\right)$, respectively. The rainfall recharge value of $0.10 \mathrm{~m} / \mathrm{yr}$, which represents 10 percent of the annual rainfall, was assumed by Giusti (1971) for the aquifer (fig. 1). Kuniansky and others (2003) used values of rainfall recharge between 4 and 12 percent of the annual rainfall for that same area. Only rainfall recharge is used in the estimate of the expected nitrate concentration because the irrigation return flow from micro-drip irrigation is assumed to be negligible (Kuniansky and others, 2003). The rainfall recharge for the western and central sections were estimated to be $1.7 \times 10^{6} \mathrm{~m}^{3} / \mathrm{yr}\left(16.8 \mathrm{~km}^{2} \times 0.10 \mathrm{~m} / \mathrm{yr}\right)$ and $3.1 \times 10^{6} \mathrm{~m}^{3} / \mathrm{yr}\left(30.8 \mathrm{~km}^{2} \times 0.10 \mathrm{~m} / \mathrm{yr}\right)$, respectively. The expected $\mathrm{NO}_{3}-\mathrm{N}$ concentration in groundwater in the central section of the study area would be as high as 32 $\mathrm{mg} / \mathrm{L}\left(99,600 \mathrm{~kg} \mathrm{~N} / \mathrm{yr}\right.$ divided by $\left.3.1 \times 10^{6} \mathrm{~m}^{3} / \mathrm{yr}\right)$. The $\mathrm{NO}_{3}-\mathrm{N}$ measured concentrations in this area ranged from 4 to 74 percent of the expected concentration. In the western section of the study area, the expected $\mathrm{NO}_{3}-\mathrm{N}$ concentration in groundwater would be as high as $27 \mathrm{mg} / \mathrm{L}\left(45,300 \mathrm{~kg} \mathrm{~N} / \mathrm{yr}\right.$ divided by $\left.1.7 \times 10^{6} \mathrm{~m}^{3} / \mathrm{yr}\right)$. The measured $\mathrm{NO}_{3}-\mathrm{N}$ concentrations in this area ranged from 42 to 77 percent of the expected concentration. 
Table 7. Estimated nitrogen load from irrigation groundwater in the central and western sections of the study area, Santa Isabel, Puerto Rico, 2008.

\begin{tabular}{|c|c|c|c|c|}
\hline Number on figure 2 & \multirow[t]{2}{*}{$\begin{array}{l}\text { Nitrate as nitrogen, } \\
\text { milligrams per liter }\end{array}$} & \multirow{2}{*}{$\begin{array}{c}\text { Average groundwater } \\
\text { withdrawal, cubic } \\
\text { meters per day }\end{array}$} & \multirow{2}{*}{$\begin{array}{l}\text { Total annual ground- } \\
\text { water withdrawal, } \\
\text { cubic meters per year }\end{array}$} & \multirow{2}{*}{$\begin{array}{c}\text { Estimated nitrogen } \\
\text { load, kilograms per } \\
\text { year }\end{array}$} \\
\hline & & & & \\
\hline 26 & 6.9 & 1,022 & 373,030 & 2,574 \\
\hline 36 & $10.0 \mathrm{E}$ & 1,438 & 524,870 & 5,249 \\
\hline 39 & 23.6 & 530 & 193,435 & 4,565 \\
\hline 41 & 10.8 & 946 & 345,290 & 3,729 \\
\hline 45 & $10.0 \mathrm{E}$ & 1,211 & 442,015 & 4,420 \\
\hline 48 & $2.0 \mathrm{E}$ & 757 & 276,305 & 553 \\
\hline 49 & 3.0 & 379 & 138,335 & 415 \\
\hline 50 & $5.0 \mathrm{E}$ & 492 & 179,618 & 898 \\
\hline 51 & 11.5 & 1,173 & 428,145 & 4,924 \\
\hline 52 & 14.2 & 1,817 & 663,205 & 9,418 \\
\hline 53 & $21.0 \mathrm{E}$ & 1,249 & 455,885 & 9,574 \\
\hline 54 & 19.9 & 1,022 & 373,030 & 7,423 \\
\hline 59 & $10.0 \mathrm{E}$ & 795 & 290,175 & 2,902 \\
\hline 60 & $10.0 \mathrm{E}$ & 1,173 & 428,145 & 4,281 \\
\hline Total & & & & 60,924 \\
\hline & & Western Section & & \\
\hline 7 & $5.0 \mathrm{E}$ & 833 & 304,045 & 1,520 \\
\hline 8 & 14.9 & 492 & 179,580 & 2,676 \\
\hline 10 & 12.9 & 492 & 179,580 & 2,317 \\
\hline 12 & $13.0 \mathrm{E}$ & 871 & 317,915 & 4,069 \\
\hline 13 & 16 & 530 & 193,450 & 3,095 \\
\hline 14 & $20.0 \mathrm{E}$ & 1,249 & 455,885 & 9,118 \\
\hline 15 & 20.9 & 909 & 331,785 & 6,934 \\
\hline 16 & $15.0 \mathrm{E}$ & 681 & 248,565 & 3,728 \\
\hline 17 & $19.0 \mathrm{E}$ & 606 & 221,190 & 4,203 \\
\hline 18 & 11.4 & 909 & 331,785 & 3,782 \\
\hline 19 & 18.5 & 416 & 151,840 & 2,809 \\
\hline 20 & 19.5 & 1,249 & 455,885 & 8,890 \\
\hline 21 & 12.4 & 454 & 165,801 & 2,056 \\
\hline 33 & 2.4 & 946 & 345,290 & 829 \\
\hline Total & & & & 5,6026 \\
\hline
\end{tabular}


Table 8. Potential nitrogen load estimates from fertilizers applied to crops and other sources in the central and western sections of the study area, Santa Isabel, Puerto Rico, 2008.

[kg N/ha-yr, kilogram of nitrogen per hectare per year; $\mathrm{N}$, nitrogen; ha, hectare; $\mathrm{kg} \mathrm{N} / \mathrm{yr}$, kilogram of nitrogen per year]

\begin{tabular}{|c|c|c|c|c|c|}
\hline Crop or source & $\begin{array}{l}\text { Fertilizer application } \\
\text { rate, kg N/ha-yr }\end{array}$ & $\begin{array}{l}\text { Crop nitrogen up- } \\
\text { take, kg N/ha-yr }\end{array}$ & $\begin{array}{c}\text { Potential residual N, } \\
\text { kg N/ha-yr }\end{array}$ & Cultivated area, ha & $\begin{array}{c}\text { Total residual N, kg } \\
\text { N/yr }\end{array}$ \\
\hline \multicolumn{6}{|c|}{ Central Section } \\
\hline Bananas & $154-340$ & $112^{\mathrm{a}}$ & $42-228$ & 40 & $1,680-9,120$ \\
\hline Corn & $225-240$ & $174^{\mathrm{a}}$ & $51-66$ & 298 & $151,98-19,668$ \\
\hline Soybeans & 225 & $219^{\mathrm{b}}$ & 6 & 0 & 0 \\
\hline Tomato & 107 & $82^{\mathrm{a}}$ & 25 & 49.3 & 1,232 \\
\hline $\begin{array}{l}\text { Vegetables and } \\
\text { papaya }\end{array}$ & $74-156$ & $18-64^{a}$ & 88 & 639 & $35,784-58,788$ \\
\hline \multicolumn{6}{|c|}{ Western Section } \\
\hline Bananas & $154-340$ & $112^{\mathrm{a}}$ & $42-228$ & 59 & $2,478-13,452$ \\
\hline Corn & $225-240$ & $174^{\mathrm{a}}$ & $51-66$ & 0 & 0 \\
\hline Mango & 78 & $42^{\mathrm{a}}$ & 36 & 78 & 2,808 \\
\hline Soybeans & 225 & $219^{\mathrm{b}}$ & 6 & 68 & 408 \\
\hline Tomato & 107 & $82^{\mathrm{a}}$ & 25 & 224 & 5,600 \\
\hline $\begin{array}{l}\text { Vegetables and } \\
\text { papaya }\end{array}$ & $74-156$ & $18-64^{\mathrm{a}}$ & 88 & 157 & $8,792-14,444$ \\
\hline
\end{tabular}

${ }^{a}$ Natural Resources Conservation Service, 2001

${ }^{\mathrm{b} S}$ Salvagiotti and others, 2008

The estimate of the expected concentration assumes that the entire estimated potential nitrogen load enters the aquifer, that there is no $\mathrm{NO}_{3}-\mathrm{N}$ accumulation in the unsaturated zone, and that groundwater flow is steady state. The unsaturated zone in the area of higher $\mathrm{NO}_{3}-\mathrm{N}$ concentration ranged from 11 to $35 \mathrm{~m}$ below land surface during 2008, which indicates that part of the calculated load could be in transient storage and some may have been released from storage. Most of the sampled wells are screened over long intervals (ranging from 32.9 to $72.8 \mathrm{~m}$ ), which means that collected samples represent a mixture of water recharged over a number of years; this fact represents a limitation to the methodology used in this study.
The expected $\mathrm{NO}_{3}-\mathrm{N}$ concentration in groundwater calculated using the current fertilizer application rates was compared to the expected $\mathrm{NO}_{3}-\mathrm{N}$ concentration during the period when sugarcane was the principal crop in the area. Sugarcane cultivation was the principal landuse activity in the area from the early 1900s until the 1970s. The fertilizer application rate to sugarcane crops ranged from 135 to $208 \mathrm{~kg} \mathrm{~N} / \mathrm{ha}-\mathrm{yr}$ (Natural Resources Conservation Service, 2001). The N uptake of sugarcane crops is estimated to range from 86 to $117 \mathrm{~kg} \mathrm{~N} / \mathrm{ha}-\mathrm{yr}$ (Natural Resources Conservation Service, 2001). Using the average values of the fertilizer application rate and the $\mathrm{N}$ uptake, the amount of $\mathrm{N}$ available for volatilization, mineralization, and potential migration to 
the aquifer would be about $70 \mathrm{~kg} / \mathrm{ha}-\mathrm{yr}$ during the period when sugarcane was the principal crop in the area.

The expected $\mathrm{NO}_{3}-\mathrm{N}$ concentration in groundwater within the same area used in the previous calculation under present land-use conditions but, for the period when sugarcane was the principal crop in the area, was estimated using a recharge rate from rainfall infiltration and furrow-irrigation return flows of $0.36 \mathrm{~m} / \mathrm{yr}$

(Fernando Gómez-Gómez, U.S. Geological Survey, oral commun., 2003) and a potential $\mathrm{N}$ load of $70 \mathrm{~kg} / \mathrm{ha}-\mathrm{yr}$. If the cultivated land area is assumed to equal the total area used in the previous calculations in this section, the potential $\mathrm{N}$ available to move into the aquifer would be $333,200 \mathrm{~kg} / \mathrm{yr}(4,760 \mathrm{ha} \times 70 \mathrm{~kg} / \mathrm{ha}-\mathrm{yr})$. The expected NO3-N concentration in the aquifer would be about $19 \mathrm{mg} / \mathrm{L}$. Concentrations of $\mathrm{NO}_{3}-\mathrm{N}$ from samples collected in wells during 1967 indicate concentrations ranged from 0.9 to $5.9 \mathrm{mg} / \mathrm{L}$ (fig. $12 B$ ) (median of $3.1 \mathrm{mg} / \mathrm{L}, \mathrm{n}=20$ ). This result indicates that measured $\mathrm{NO}_{3}-\mathrm{N}$ concentrations in the aquifer range from 5 to 31 percent of the expected concentrations calculated from the potential $\mathrm{N}$ load. Consequently, a large portion of the $\mathrm{N}$ fertilizer load may have been lost to volatilization or soil mineralization, or was in transient storage.

Given the uncertainty of the methodology used, a comparison of the relation between the potential nitrogen loads to the aquifer with the groundwater $\mathrm{NO}_{3}-\mathrm{N}$ concentrations - for the historical and present land-use conditions - indicates that as much 77 percent of the estimated fertilizer residual load can reach the aquifer within cropland areas under the existing land-use conditions and fertilizer application rates in the study area.

\section{Summary and Conclusions}

Between January 2008 and May 2009, the U.S. Geological Survey conducted a study to evaluate the groundwater-quality and selected hydrologic conditions in the South Coast aquifer, Santa Isabel area and in the Gabia area, a semi-enclosed basin in the foothills north of the coastal plain. Agriculture is the principal land use within the study area, which includes truck-farm crops, bioengineered crops for seed production, and confined animal feeding operations. The study area includes part of the South Coast aquifer and bedrock hills north of the coastal plain. The principal groundwater flow zone within the study area is within the fan-delta and alluvial deposits. These deposits in the study area have a thickness of as much as 300 meters (m) along the coast. The hills north of the coastal plain consist of volcanic rocks. Hydraulic conductivity in the Río Coamo fan ranges from less than 1 meter per day $(\mathrm{m} / \mathrm{d})$ to approximately $80 \mathrm{~m} / \mathrm{d}$, with the depth to groundwater during 2008 ranging from 3 to $35 \mathrm{~m}$ below land surface.

A water-table map prepared during the study indicates that the general groundwater flow direction is southward and also indicates the presence of two cones of depression, one in the north central part of the study area and another in the southwestern part of the study area. The water-table altitude during 2008 was approximately $4 \mathrm{~m}$ lower, on average, than it was in 1986 during a similar study. Groundwater withdrawals from the aquifer were estimated to be approximately 64,400 cubic meters per day $\left(\mathrm{m}^{3} / \mathrm{d}\right)$ in 2008. In 2008, 51 percent of total groundwater withdrawals in the Santa Isabel area were for agriculture and 49 percent were for public water supply.

Estimated dissolved-solids concentrations for groundwater in the study area, determined from specific conductance data, ranged from 384 to 2,090 milligrams per liter $(\mathrm{mg} / \mathrm{L})$ in wells in the coastal plain. Estimated dissolved-solids concentrations below $500 \mathrm{mg} / \mathrm{L}$ were detected parallel to Río Coamo.

Groundwater samples collected at 10 wells in the study area were analyzed for 83 organic compounds used as pesticides. Analytical results indicated that 13 of these organic compounds were detected in the samples. The detected organic compounds included 8 herbicides, 3 fungicides, and 2 insecticides.

Nitrate concentrations above the U.S. Environmental Protection Agency maximum contaminant level (MCL) of $10 \mathrm{mg} / \mathrm{L}$ for drinking water were detected in 15 wells sampled in the coastal plain and 1 well in the foothills. All wells exceeding the nitrate MCL are used for agricultural purposes.

Sources of nitrate in the study area are associated with soil nitrate and fertilizers used in the cultivated farmlands and organic waste from leakage of sewer mains or septic systems. Groundwater samples analyzed for the stable isotope ratios of $\delta^{15} \mathrm{~N}$ and $\delta^{18} \mathrm{O}$ in nitrate suggest that nitrate concentrations are associated with leakage from sewer mains or septic systems in northcentral, south-central, and eastern parts of the study area. Values of $\delta^{15} \mathrm{~N}$ and $\delta^{18} \mathrm{O}$ in samples from wells located in the western and central parts of the study area were in the range typically associated with soil nitrogen. Potential nitrogen loads from areas under cultivation were estimated for the principal crops in the area. Principal potential nitrogen loads were associated to fertilizer use at vegetable and papaya farms $(70,048 \mathrm{~kg}-\mathrm{N} / \mathrm{ha}-\mathrm{yr})$, corn farms $(15,198$ to $19,668 \mathrm{~kg}-\mathrm{N} / \mathrm{yr})$, banana farms $(8,064$ to $43,778 \mathrm{~kg}-\mathrm{N} / \mathrm{yr})$, and mango farms $(13,644 \mathrm{~kg}-\mathrm{N} / \mathrm{yr})$.

Nitrate concentrations above the maximum contaminant level (MCL) indicate the movement of nitrogen to the soil and aquifer. An increase in fertilizer application would be expected to increase nitrogen movement to the soil and the aquifer and a decrease 
would be expected to have the opposite effect. Fertilizer management in farms in the study area should account for the amount of $\mathrm{NO}_{3}-\mathrm{N}$ present in groundwater used for crop irrigation, which in the central and western sectors of the study area, ranged from 1.3 to $23.6 \mathrm{mg} / \mathrm{L}$ and from 11.4 to $20.9 \mathrm{mg} / \mathrm{L}$, respectively, in 2008 . The nitrogen content of crop residues may also be evaluated to determine if it is a substantial source that can increase the nitrate concentrations in the aquifer.

Increased use of surface water from the Canal de Juana Díaz for the irrigation of crops in the Santa Isabel area would reduce the need for groundwater withdrawals from the aquifer. The reduction of groundwater withdrawals would be expected to increase groundwater levels in the aquifer, maintain the groundwater flow towards the coast, and decrease the potential of inland movement of seawater. In addition, a decrease in the use of groundwater would potentially reduce the nitrogen load to the aquifer as surface water with lower nitrogen concentration is applied to the crops.

\section{References Cited}

Bennett, G.D., 1976, Electrical analog simulation of the aquifers along the South Coast of Puerto Rico: U.S. Geological Survey Open-File Report 74-1010, 101 p.

Briggs, R.P., and Akers, J.P., 1965, Hydrogeologic map of Puerto Rico and adjacent islands, U.S. Geological Survey Hydrologic Investigations Atlas HA-197, 1 sheet.

Casciotti, K.L., Sigman, D.M., Galanter Hastings, M., Böhlke, J.K., and Hilkert, A., 2002, Measurement of the oxygen isotopic composition of nitrate in seawater and freshwater using the denitrifier method: Analytical Chemistry, v. 74, p. 4905-4912.

Chapelle, F.H., 1993, Ground-water microbiology and geochemistry: New York, John Wiley and Sons, 424 p.

Clark I.D. and Fritz, P., 1997, Environmental isotopes in hydrogeology: Boca Raton, Florida, CRC Press LLC, $328 \mathrm{p}$.

Coplen, T.B., 1988, Normalization of Oxygen and Hydrogen Isotope Data, Chemical Geology (Isotope Geoscience Section), v. 72, p. 293-297.

Coplen, T.B., 1994, Reporting of stable hydrogen, carbon, and oxygen isotopic abundances: Pure and Applied Chemistry, v. 66, p. 273-276
Díaz, J.R., 1979, Seawater intrusion, south coast of Puerto Rico, 1966-77, U.S. Geological Survey Open-File Report 79-1334, 20 p.

Giusti, E.V., 1971, Water resources of the Coamo area, Puerto Rico: U.S. Geological Survey Water-Resources Bulletin 9, $31 \mathrm{p}$

Glover, Lynn, 1961, Preliminary geologic map of the Salinas quadrangle: U.S. Geological Survey Miscellaneous Geologic Investigations Map I-337.

Glover, Lynn, and Mattson, P.H., 1973, Geologic map of the Río Descalabrado quadrangle: U.S. Geological Survey Miscellaneous Geologic Investigations Map I-735.

Glover, Lynn, Pease, M.H., and Arnow, Theodore, 1977, Surficial geologic map of the Playa de Ponce and Santa Isabel quadrangles: U.S. Geological Survey Miscellaneous Field Studies Map MF-886.

Gómez-Gómez, Fernando, 1991, Hydrochemistry of the South Coastal Plain aquifer system of Puerto Rico and its relation to surface-water recharge, in GómezGómez, F., Quiñones-Aponte, V., and Johnson, A.I., eds., Regional aquifer systems of the United States, aquifers of the Caribbean Islands: American Water Resources Association Monograph Series no. 15, p. 57-75.

Gustafson, D.I., 1989, Groundwater ubiquity score: A simple method for assessing pesticide leachability: Environmental Toxicology and Chemistry, v. 8, p. 339-357.

Hem, J.D., 1986, Study and interpretation of the chemical characteristics of natural water: U.S. Geological Survey Water-Supply Paper 2254, 263 p.

Iker, B.C., Kombesis, Pat, Oehrle, S.A., Groves, Chris, and Barton, H.A., 2010, Microbial atrazine breakdown in a karst groundwater system and its effect on ecosystem energetics: Journal of Environmental Quality, v. 39, p. 509-518.

Kaplan, O.B., 1987, Septic systems handbook: Chelsea, Mich., Lewis Publishers, 290 p.

Kendall, Carol, 1998, Tracing nitrogen sources and cycling in catchments, in Kendall, C., and McDonnell, J.J., eds., Isotopes tracers in catchment hydrology: Amsterdam, Elsevier Science B.V., p. 519-576. 
Kuniansky, E.L., Gómez-Gómez, Fernando, and Torres-González, Sigfredo, 2004, Effects of aquifer development and changes in irrigation practices on ground-water availability in the Santa Isabel area, Puerto Rico: U.S. Geological Survey Water-Resources Investigations Report 03-4303, 56 p.

Mariotti, A., 1983, Atmospheric nitrogen is a reliable standard for natural $15 \mathrm{~N}$ abundance measurements: Nature, v. 303, p. 685-687.

Mayer, B., 2005, Assessing sources and transformations of sulphate and nitrate in the hydrosphere using isotopes techniques, in Aggarwal, P.K., Gat, J.R., and Froehlich, K.F.O., eds., Isotopes in the water cyclepast, present, and future of a developing science: The Netherlands, Springer, p. 67-89.

Molina-Rivera, W.L., and Gómez-Gómez, Fernando, 2008, Estimated water use in Puerto Rico, 2005: U.S. Geological Survey Open-File Report 2008-1286, 37 p.

Monroe, W.H., 1980, Geology of the middle Tertiary Formations of Puerto Rico, U.S. Geological Survey Professional Paper 953, 93 p., 1 pl.

Natural Resources Conservation Service, 2001, Nutrient management: Natural Resources Conservation Service, Caribbean Area, Conservation Practice Standard, Technical Guide Section IV, 41 p.

Renken, R.A., Ward, W.C., Gill, I.P., Gómez-Gómez, Fernando, and Rodríguez-Martínez, Jesús, 2002, Geology and hydrogeology of the Caribbean Islands aquifer System of the Commonwealth of Puerto Rico and the U.S. Virgin Islands: U.S. Geological Survey Professional Paper 1419, 139 p.

Revesz, K., and Casciatti, K., 2003, Nitrogen and oxygen isotope ratio analysis of dissolved nitrate by the denitrifier method using continuous flow isotope ratio mass spectrometry: Standard Operation Procedure (SOP) \#2900, Techniques of the U.S. Geological Survey, In preparation.

Richards, L.A, ed., 1954, Diagnosis and improvement of saline and alkali soils: Washington D.C., U.S. Department of Agriculture Handbook no. 60, 160 p.

Rodríguez-del-Río, Félix, and Gómez-Gómez, Fernando, 1990, Potentiometric surface of the alluvial aquifer and hydrologic conditions in the Santa Isabel-Juana Díaz area, Puerto Rico, March to April 1987: U.S. Geological Survey Water-Resources Investigations Report 89-4116, 1 sheet.
Rodríguez, J.M., and Gómez-Gómez, F., 2008, Groundwater-quality survey of the South Coast Aquifer of Puerto Rico, April 2 through May 30, 2007: U.S. Geological Survey Scientific Investigations Map 3092, 1 sheet.

Salvagiotti, F., Cassman, K.G., Specht, J.E., Walters, D.T., Weiss, A., and Dobermann, A., 2008, Nitrogen uptake, fixation and response to fertilizer $\mathrm{N}$ in soybeans: A review: Field Crops Research, v. 108, p. 1-13.

Sigman, D.M., Casciotti, K.L., Andreani, M., Barford, C., Galanter, M., and Böhlke, J.K., 2001, A bacterial method for the nitrogen isotopic analysis of nitrate in seawater and freshwater: Analytical Chemistry, v. 73, p. 4145-4153.

Thurman, E.M., and Fallon, J.D., 1996, The deethylatrazine/atrazine ratio as an indicator of the onset of the spring flush of herbicides into surface water of the Midwestern United States: International Journal of Environmental Analytical Chemistry, v. 65, p. 203-214.

U.S. Census Bureau, 2002, Census 2000 profile of general demographic characteristics: U.S. Census Bureau, http://factfinder.census.gov, accessed July 14, 2009.

U.S. Environmental Protection Agency, 2009, National Primary Drinking Water Regulations: EPA 816-F-09-004, May 2009.

U.S. Geological Survey, variously dated, National field manual for the collection of water-quality data: U.S. Geological Survey Techniques of Water-Resources Investigations, book 9, chaps. A1-A9.

U.S. Geological Survey, 2012, National Water Information System: U.S. Geological Survey database, accessed May 19, 2009 at http://waterdata.usgs.gov/pr/ nwis/. 

Appendix 


\section{Appendix. Pesticides analyzed from groundwater samples collected in the Santa Isabel area, Puerto Rico, 2008.}

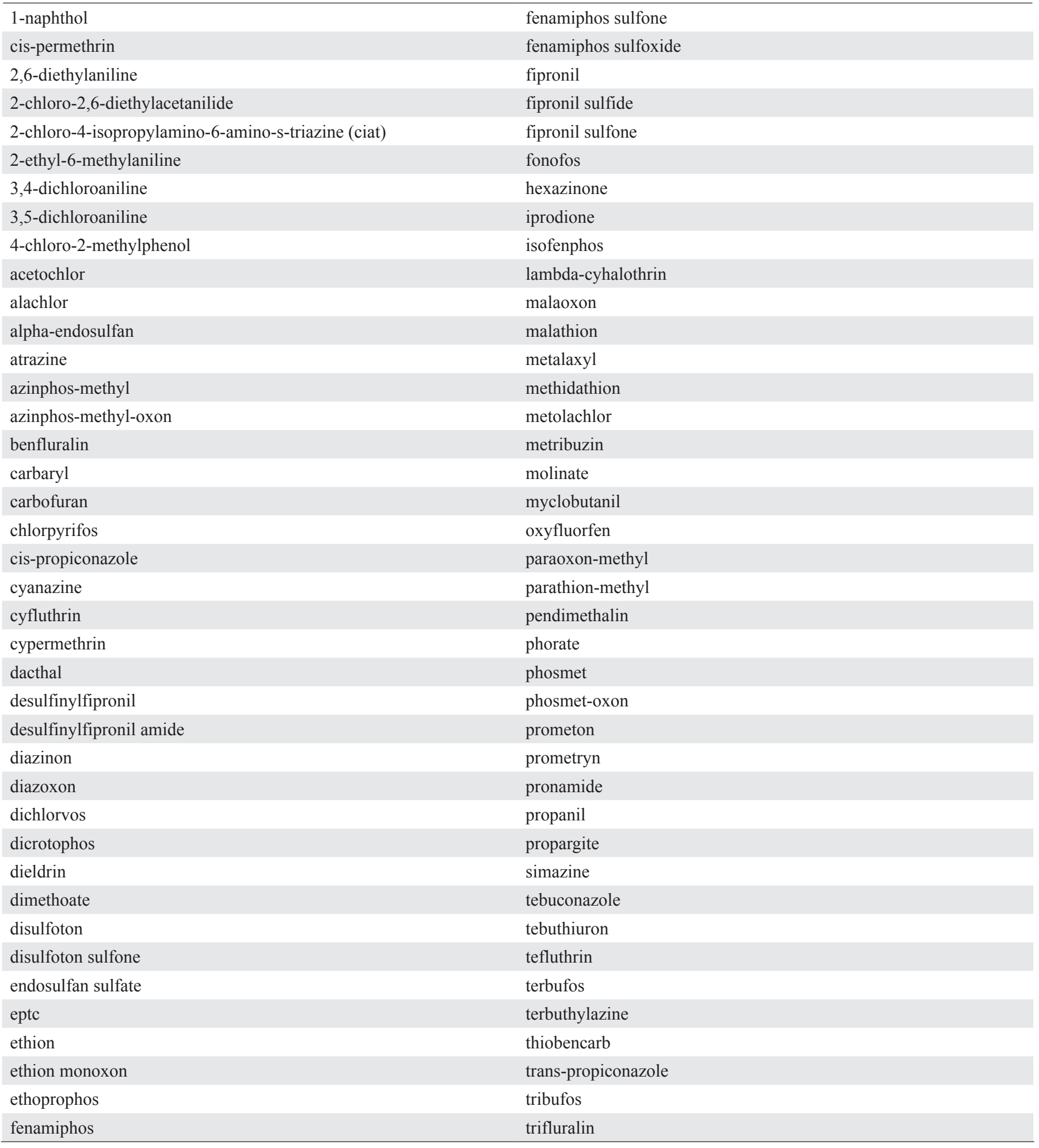


Prepared by the Raleigh Publishing Service Center

For additional information contact:

Jose M. Rodriguez

Caribbean Water Science Center

GSA Center

651 Federal Drive, Suite 400-15

Guaynabo, PR 00965

(787) $749-7400$

or visit the Caribbean Water Science Center at: http://pr.water.usgs.gov/ 


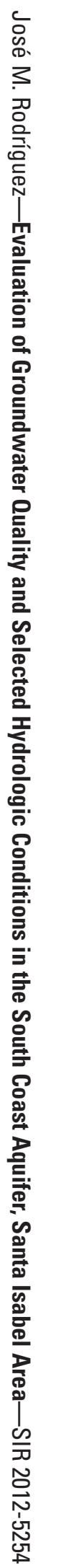

